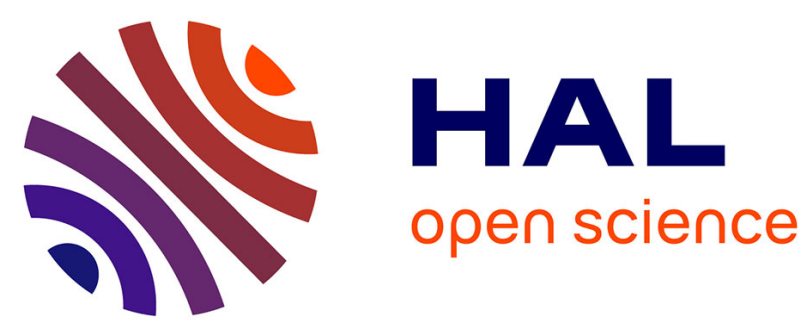

\title{
Optical Properties of Secondary Organic Aerosol Produced by Nitrate Radical Oxidation of Biogenic Volatile Organic Compounds
}

Quanfu He, Sophie Tomaz, Chunlin Li, Ming Zhu, D. Meidan, M. Riva, Alexander Laskin, S. Brown, C. George, Xinming Wang, et al.

\section{To cite this version:}

Quanfu He, Sophie Tomaz, Chunlin Li, Ming Zhu, D. Meidan, et al.. Optical Properties of Secondary Organic Aerosol Produced by Nitrate Radical Oxidation of Biogenic Volatile Organic Compounds. Environmental Science and Technology, 2021, 55 (5), pp.2878-2889. 10.1021/acs.est.0c06838 . hal03199881

\section{HAL Id: hal-03199881 \\ https://hal.science/hal-03199881}

Submitted on 13 Oct 2021

HAL is a multi-disciplinary open access archive for the deposit and dissemination of scientific research documents, whether they are published or not. The documents may come from teaching and research institutions in France or abroad, or from public or private research centers.
L'archive ouverte pluridisciplinaire $\mathbf{H A L}$, est destinée au dépôt et à la diffusion de documents scientifiques de niveau recherche, publiés ou non, émanant des établissements d'enseignement et de recherche français ou étrangers, des laboratoires publics ou privés. 


\section{Optical Properties of Secondary Organic Aerosol Produced by Nitrate Radical Oxidation of Biogenic Volatile Organic Compounds}

Quanfu He, Sophie Tomaz, Chunlin Li, Ming Zhu, Daphne Meidan, Matthieu Riva, Alexander Laskin, Steven S. Brown, Christian George, Xinming Wang, and Yinon Rudich*

Cite This: Environ. Sci. Technol. 2021, 55, 2878-2889

Read Online

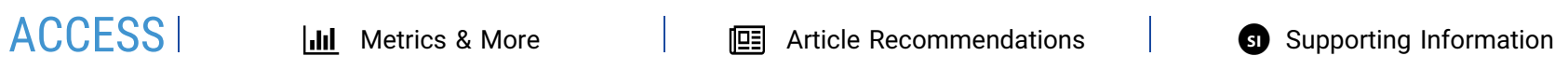

ABSTRACT: Nighttime oxidation of biogenic volatile organic compounds (BVOCs) by nitrate radicals $\left(\mathrm{NO}_{3} \cdot\right)$ represents one of the most important interactions between anthropogenic and natural emissions, leading to substantial secondary organic aerosol (SOA) formation. The direct climatic effect of such SOA cannot be quantified because its optical properties and atmospheric fate are poorly understood. In this study, we generated SOA from the $\mathrm{NO}_{3}$. oxidation of a series BVOCs including isoprene, monoterpenes, and sesquiterpenes. The SOA were subjected to comprehensive online and offline chemical composition analysis using high-resolution mass spectrometry and optical properties measurements using a novel broadband (315-650 nm) cavity-

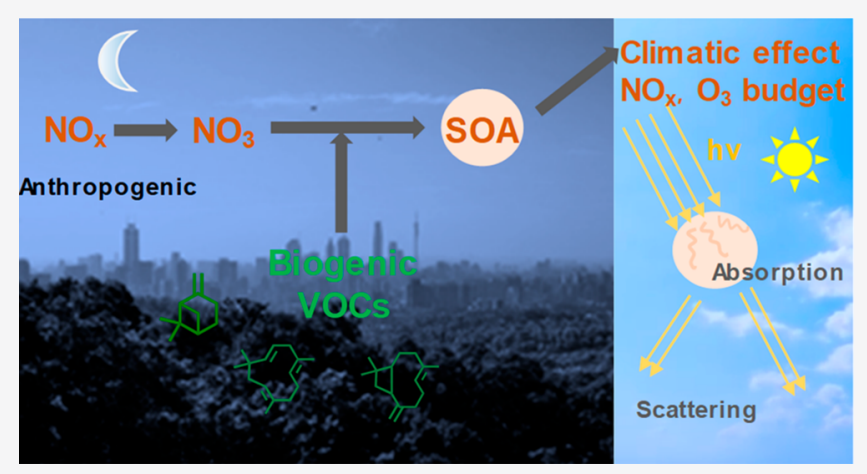
enhanced spectrometer, which covers the wavelength range needed to understand the potential contribution of the SOA to direct radiative forcing. The SOA contained a significant fraction of oxygenated organic nitrates (ONs), consisting of monomers and oligomers that are responsible for the detected light absorption in the 315-400 nm range. The SOA created from $\beta$-pinene and $\alpha$-humulene was further photochemically aged in an oxidation flow reactor. The SOA has an atmospheric photochemical bleaching lifetime of $>6.2 \mathrm{~h}$, indicating that some of the ONs in the SOA may serve as atmosphere-stable nitrogen oxide sinks or reservoirs and will absorb and scatter incoming solar radiation during the daytime.

\section{INTRODUCTION}

Atmospheric secondary organic aerosols (SOAs) affect radiative forcing by aerosol-radiation interactions and through aerosol-cloud interactions. ${ }^{1,2}$ Specifically, SOAs contain lightabsorbing compounds, also called brown carbon $(\mathrm{BrC})$, and play a significant role in the direct climate forcing on regional and local scales. ${ }^{3,4}$ Owing to the high emission rates and high reactivities with primary atmospheric oxidants, such as ozone, the hydroxyl radical $(\mathrm{OH} \cdot)$, and the nitrate radical $\left(\mathrm{NO}_{3} \cdot\right)$, vegetation-emitted biogenic volatile organic compounds (BVOCs), such as isoprene $\left(\mathrm{C}_{5} \mathrm{H}_{8}\right)$, monoterpenes $\left(\mathrm{C}_{10} \mathrm{H}_{16}\right)$, and sesquiterpenes $\left(\mathrm{C}_{15} \mathrm{H}_{24}\right)$, are the major contributors to the global SOA burden. ${ }^{5-9}$

Whereas $\mathrm{OH}$. and ozone $\left(\mathrm{O}_{3}\right)$ play a key role during daytime atmospheric oxidation, $\mathrm{NO}_{3}$. is a dominant oxidant at night, especially in environments affected by anthropogenic emissions. ${ }^{10} \mathrm{NO}_{3} \cdot$ is formed by the reaction of nitrogen dioxide and $\mathrm{O}_{3}$ and reaches atmospheric concentrations up to hundreds of parts per trillion (ppt). ${ }^{112}$ Field studies have shown that under conditions with moderate to high BVOC levels, $\mathrm{NO}_{3} \cdot$ predominantly reacts with $\mathrm{BVOCs}{ }^{12}$ to produce multifunctional compounds such as organic nitrates (ONs). ${ }^{13-16}$ Because of their semivolatile/low-volatility nature, ONs can partition in the particle phase either by condensing onto pre-existing particles or by forming new SOA particles. $^{13,17,18}$ Chamber studies have shown that the SOA mass yields from $\mathrm{BVOC}+\mathrm{NO}_{3}$. reactions vary between 0.2 and $146 \%$ and that the $\mathrm{ON}$ molar yields range between 10 and $78 \%{ }^{7}$ The results from field measurements have also shown that the nocturnal $\mathrm{NO}_{3}$-initiated oxidation of BVOCs contributes a significant fraction to ambient particulate nitrates $^{19-22}$ and organic aerosols ${ }^{23-26}$ that influence the air quality, human health, and the climate. Moreover, particlephase ONs can either release nitrogen oxides $\left(\mathrm{NO}_{x}=\mathrm{NO}+\right.$ $\mathrm{NO}_{2}$ ) back into the atmosphere via further oxidation reactions and photolysis or act as terminal $\mathrm{NO}_{x}$ sinks through hydrolysis and particle deposition. Therefore, ONs play essential roles in the atmosphere and biosphere because they affect tropospheric $\mathrm{O}_{3}$ production and the global nitrogen cycle.

Although the oxidation of BVOCs by $\mathrm{NO}_{3}$. represents a critical interaction between anthropogenic and biogenic

Received: October 11, 2020

Revised: December 30, 2020

Accepted: February 3, 2021

Published: February 17, 2021

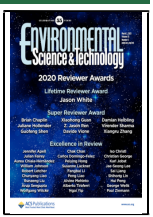


emissions, the direct radiative effects of the SOA from this process are not well constrained, in part because their optical properties are not yet insufficiently described. ${ }^{27}$ Whereas most of the existing literature on the optical properties of BVOCderived SOAs has mainly focused on $\mathrm{OH}$ - oxidation or ozonolysis, ${ }^{27-33}$ studies on the optical properties of the biogenic SOA formed by $\mathrm{NO}_{3}$. oxidation $\left(\mathrm{BSOA}_{\mathrm{NO}_{3}}\right)$ are rare. The few studies that examined the $\mathrm{BSOA}_{\mathrm{NO}_{3}}$ reached partially contradictory conclusions. ${ }^{34-37}$ For instance, the real part of the refractive index (RI) for the SOA from the $\mathrm{NO}_{3}$. oxidation of $\beta$-pinene and limonene was higher than those observed following $\mathrm{OH}$ - and ozone-initiated terpene oxidation. ${ }^{35,37}$ However, the real part of the RI for the SOA from the $\mathrm{NO}_{3}$. oxidation of isoprene seems to be similar to that of $\mathrm{OH}$. and ozone-initiated oxidation. ${ }^{34}$ Moreover, absorption was not detected for the SOA from the $\mathrm{NO}_{3}$. oxidation of isoprene, $\beta$ pinene, and limonene, but significant light absorption at 355 and $405 \mathrm{~nm}$ was detected for the SOA formed by $\mathrm{NO}_{3} \cdot+\alpha$ pinene. $^{36}$ Washenfelder et al. $^{38}$ measured aerosol optical properties at a forest site in rural Alabama during the 2013 Southern Oxidant and Aerosol Study (SOAS) campaign. They reported that $\sim 7 \%$ of $\mathrm{BrC}$ absorption could be attributed to the less oxidized oxygenated organic aerosol (LO-OOA) that reached a diel maximum at night and was correlated with particle-phase ONs, formed by nighttime reactions between monoterpenes and $\mathrm{NO}_{3} \cdot{ }^{23}$ These findings suggest that the SOA produced from reactions of $\mathrm{NO}_{3}$. with BVOCs may be a nighttime source of $\mathrm{BrC}$ that may affect the direct radiative effect of the SOA through the scattering and absorption of solar radiation. The optical properties of the $\mathrm{BSOA}_{\mathrm{NO}_{3}}$ and its fate during daytime photooxidation remain unclear.

In this study, the representative $\mathrm{BSOA}_{\mathrm{NO}_{3}}$ was produced by reactions of the most common BVOCs, such as isoprene, terpenes, and sesquiterpenes, with $\mathrm{NO}_{3}$. We determined the scattering and absorption optical properties of the $\mathrm{BSOA}_{\mathrm{NO}_{3}}$ over a very broad wavelength range $(315-650 \mathrm{~nm})$ for the first time. These optical properties are needed to understand their potential contributions to direct radiative forcing. We investigated the relationship between the SOA formation mechanism, the SOA's chemical composition, and the measured optical properties. We show that the absorbing particulate organic nitrates have a lifetime $>6 \mathrm{~h}$ upon the transition from nighttime to daytime oxidation. This study thus emphasizes the role of this important chemistry in the climate, air quality, and atmospheric nitrogen cycle.

\section{METHODS}

2.1. SOA Generation with $\mathbf{N O}_{3} \cdot$ Oxidation. BVOCs (isoprene, monoterpenes ( $\beta$-pinene and $\delta^{3}$-carene), and sesquiterpenes ( $\alpha$-cedrene, $\beta$-caryophyllene, and $\alpha$-humulene)) were introduced into a glass oxidation flow reactor $\left(\mathrm{OFR}_{\mathrm{NO}_{3}}\right.$ L: $\left.70 \mathrm{~cm}, \mathrm{ID}: 7 \mathrm{~cm}\right)$ from a temperature-controlled glass reservoir. The target mixing ratio of the VOCs was achieved by controlling the flow rate through the glass reservoir and the bath temperature $\left(-50\right.$ to $\left.+50{ }^{\circ} \mathrm{C}\right)$. The $\mathrm{NO}_{3} \cdot$ radical was produced by the thermal decomposition of synthetic $\mathrm{N}_{2} \mathrm{O}_{5}$ (Supporting Information (SI), Text S1). The initial mixing ratio of $\mathrm{N}_{2} \mathrm{O}_{5}$ was measured by a cavity ringdown system working at $662 \mathrm{~nm}$ (Text S2). Pure nitrogen that had been passed through the $\mathrm{N}_{2} \mathrm{O}_{5}$ crystal cold trap was mixed with dry synthetic air containing the BVOCs in the $\mathrm{OFR}_{\mathrm{NO}_{3}}$ to produce $\mathrm{BSOA}_{\mathrm{NO}_{3}}$ particles by homogeneous nucleation and condensation following the $\mathrm{NO}_{3}$. oxidation. The produced particles were then subjected to online and offline chemicalphysical analysis (Figure S1). The total laminar flow in the reactor was $1.0 \mathrm{~L} \mathrm{~min}^{-1}$ (Reynolds number $\approx 20$ ) with a corresponding residence time of $162 \mathrm{~s}$. The initial conditions, including the $\mathrm{BVOC}$ mixing ratios and $\mathrm{N}_{2} \mathrm{O}_{5}$ /VOC ratios, are summarized in Table S1.

2.2. Photochemical Aging and Photolysis of the $\mathrm{BSOA}_{\mathrm{NO}_{3}}$. The $\mathrm{BSOA}_{\mathrm{NO}_{3}}$ produced in the $\mathrm{OFR}_{\mathrm{NO}_{3}}$ from $\beta$ pinene and $\alpha$-humulene was further aged by $\mathrm{OH}$ - and photolysis in a potential aerosol mass (PAM) oxidation flow reactor (OFR). Gas-phase species produced in the $\mathrm{OFR}_{\mathrm{NO}_{3}}$ were removed by a charcoal denuder before the PAM reactor. $\mathrm{OH}$ - was generated by UV photolysis (at $254 \mathrm{~nm}$ ) of 19.6 ppmv $\mathrm{O}_{3}$ under $37.5 \%$ relativ humidity $(\mathrm{RH})$. The total flow rate in the PAM was $3.2 \mathrm{~L} \mathrm{~min}^{-1}$, with a corresponding residence time of $252 \mathrm{~s}$. The operational details can be found in our previous study. ${ }^{33} \mathrm{OH}$. exposure (the combination of $\mathrm{OH}$. concentration and residence time) was determined by tracking the decay of $\mathrm{SO}_{2}$ in the PAM reactor. The equivalent $\mathrm{OH}$. aging time was $24 \mathrm{~h}$ (assuming a daily average $\mathrm{OH}$. concentration of $1.5 \times 10^{6}$ molecules $\mathrm{cm}^{-3}$ ). Although the $\mathrm{O}_{3}$ concentration is higher than that of $\mathrm{OH} \cdot$, the much higher reactive uptake coefficient and reactivity of $\mathrm{OH}$. ensure that the $\mathrm{OH}$. plays a major role in the chemical aging process in the PAM reactor. Photolysis experiments were performed in the PAM reactor in the absence of $\mathrm{O}_{3}$ for comparison with the $\mathrm{OH}$ - aging experiments. Because the light emission spectrum of the UV lamps inside the PAM reactor is different from the ambient solar spectrum, the photolysis in the PAM reactor is converted to effective photolysis under ambient conditions by considering the actinic flux and the quantum yield of the SOA products. The calculation of the effective photolysis time is briefly described here with more information in the SI (Text S3, Figure S2). The quantum yields for the photolysis reactions of the SOA constitutes are unknown. In the generated SOA, many carbonyl and nitrate groups were detected. Moreover, the extracted absorption spectra (Figure S3) suggest the presence of carbonyl nitrates. (See Section 3.3.) Thus we assume a unified quantum yield of 0.9 , as recommended for carbonyl nitrates by previous studies. ${ }^{39,40}$ The photolysis rate under the experimental conditions is then integrated over the 250-350 $\mathrm{nm}$ spectrum by considering the light absorption, quantum yield, and photon flux in the PAM. In addition, solar photolysis rates for the $\mathrm{BSOA}_{\mathrm{NO}_{3}}$, considering the daily averaged actinic flux under cloudless ground-level conditions (Rehovot, Israel on December 17, 2019, albedo of 0.19), were also estimated. Dividing the photolysis effect (the combined product of the photolysis time and the photolysis rate) in the PAM by the solar photolysis rate yields the effective photolysis time, which was $\sim 0.8 \mathrm{~h}$.

2.3. Chemical Box Modeling and Photolysis Time Estimation. To track the oxidation process in the OFR, a chemical-box model that includes gas-phase reactions of BVOCs $+\mathrm{NO}_{3}{ }^{41}$ conversions between $\mathrm{NO}_{3} \cdot$ and $\mathrm{N}_{2} \mathrm{O}_{5}$, the heterogeneous reactive uptake of $\mathrm{NO}_{3} \cdot$ and $\mathrm{N}_{2} \mathrm{O}_{5},{ }^{42,43}$ and wall losses of $\mathrm{NO}_{3}$. and $\mathrm{N}_{2} \mathrm{O}_{5}$ was used to investigate the fates of BVOCs, $\mathrm{NO}_{3}$, and $\mathrm{N}_{2} \mathrm{O}_{5}$ in the OFR (Text S4, Tables S2-S4, and Figure $\mathrm{S} 4$ ). Because of the high reaction rates of BVOCs with $\mathrm{NO}_{3} \cdot$, the BVOCs were completely (>99\%) consumed in the OFR, except for isoprene $(60 \%)$, which has a much slower 
rate constant with $\mathrm{NO}_{3}$ as compared with the other studied BVOCs. The $\mathrm{N}_{2} \mathrm{O}_{5}$ loss was dominated by wall loss (34-84\%), whereas the thermal dissociation of $\mathrm{N}_{2} \mathrm{O}_{5}$ to produce $\mathrm{NO}_{3}$. was also significant (13-64\%), as shown in Table S3. For experiments run at a $\mathrm{N}_{2} \mathrm{O}_{5} / \mathrm{VOC}$ ratio of $<3$, the amount of $\mathrm{NO}_{3}$. or $\mathrm{N}_{2} \mathrm{O}_{5}$ taken up by the particles was negligible compared with the consumption of $\mathrm{NO}_{3}$. by VOCs. However, at a high $\mathrm{N}_{2} \mathrm{O}_{5} /$ VOC ratio $(>3)$, the $\mathrm{NO}_{3}$. and $\mathrm{N}_{2} \mathrm{O}_{5}$ uptake by particles became considerable, indicating the importance of the heterogeneous reaction in the reactor. Moreover, the integrated $\mathrm{NO}_{3} \cdot$ exposures $\left(\mathrm{NO}_{3}\right.$ exposure $\left.=\sum_{0}^{t}\left[\mathrm{NO}_{3}\right] \mathrm{d} t\right)$ throughout the OFR ranged between 5.4 and $64.9 \times 10^{11}$ molecules $\mathrm{cm}^{-3} \mathrm{~s}$, which equals $0.3-3.5 \mathrm{~h}$ of ambient exposure by $\mathrm{NO}_{3}$, assuming a typical concentration of 20 pptv at night. ${ }^{44,45}$

2.4. Online and Offline Chemical-Physical Characterization of the $\mathrm{BSOA}_{\mathrm{NO}_{3}}$. The particle size distribution was continuously monitored with a scanning mobility particle sizer (SMPS, TSI) and an aerosol aerodynamic classifier (AAC, Cambustion, U.K.). The ratio of the aerodynamic and mobility size was then used to determine the particle effective density. A high-resolution time-of-flight aerosol mass spectrometer (HRTof-AMS, Aerodyne) was employed to measure the nonrefractory components (e.g., organics, nitrate) of the SOA in alternating $\mathrm{V}$ and $\mathrm{W}$ mode. Elemental ratios (e.g., $\mathrm{H} / \mathrm{C}, \mathrm{O} / \mathrm{C}$, $\mathrm{N} / \mathrm{C}$ ) and the fragment composition were extracted and corrected. $^{46,47}$ The detected ions in the mass spectra were classified into five categories based on their elemental compositions, namely, hydrocarbon-like $\left(\mathrm{C}_{x} \mathrm{H}_{y}^{+}\right)$, less oxygenated $\left(\mathrm{C}_{x} \mathrm{H}_{y} \mathrm{O}^{+}\right)$, more oxygenated $\left(\mathrm{C}_{x} \mathrm{H}_{y} \mathrm{O}_{z}^{+}\right)$, nitrogencontaining $\left(\mathrm{C}_{x} \mathrm{H}_{y} \mathrm{O}_{i} \mathrm{~N}_{j}^{+}\right)$organic components, and nitrogen oxides $\left(\mathrm{NO}_{y}^{+}\right)$, where $x, y, i$, and $j \geq 1$ and $z>1$.

SOA particles were collected on PTFE filters $(0.45 \mu \mathrm{m}$ porosity, $47 \mathrm{~mm}$ diameter, Whatman). Filters were stored at $-20{ }^{\circ} \mathrm{C}$ before analysis. The filters were extracted, and the filtrate was concentrated and analyzed by ultra-high-performance liquid chromatography (UPLC) equipped with a photodiode array (PDA) detector (spectra detection range of 200-800 nm) followed by a Q-Exactive hybrid quadrupoleOrbitrap mass spectrometer (Orbitrap MS) with a standard heated electrospray ionization ${ }^{48}$ source. The raw data were acquired using Xcalibur (Thermal Scientific) software. The data were then processed with an open-source software toolbox, MZmine 2.39 (http://mzmine.github.io/), to perform peak deconvolution and chromatogram construction. Formula assignments were completed using the following constraints: $\mathrm{C}$ $\leq 50, \mathrm{H} \leq 100, \mathrm{~N} \leq 4, \mathrm{O} \leq 50$, and $\mathrm{Na} \leq 1$. (The latter is for positive mode only.) Details of the sample preparation, column separation, instrument configurations, and settings of MZmine 2.39 are provided in Text S5.

2.5. Optical Properties Measurement and RI Retrieval. The light extinction by size-selected SOA particles in the solar spectral region $(315-650 \mathrm{~nm})$ was measured by a twochannel broadband cavity-enhanced spectrometer (BBCES). The UV channel measures the light extinction between 315 and $350 \mathrm{~nm}\left(\mathrm{BBCES}_{\mathrm{UV}}\right),{ }^{4,50}$ and the visible channel works between 380 and $\left.650 \mathrm{~nm}\left(\mathrm{BBCES}_{\mathrm{vis}}\right)\right)^{33}$ High-reflectivity mirrors (FiveNine Optics, U.S.) were installed in the $\mathrm{BBCES}_{\mathrm{vis}}$. The mirror loss measured using $\mathrm{N}_{2}$ and $\mathrm{He}$ ranged from 86 to $494 \mathrm{ppm}$ in the wavelength range of $380-650 \mathrm{~nm}$. The low mirror loss ensures high sensitivity and low uncertainty in the aerosol light extinction measurements. The complex refractive index $(\mathrm{RI}=n+i k)$ is an intrinsic optical property of a particle. The real $(n)$ and imaginary $(k)$ parts of the complex RI are indicative of scattering and absorption, respectively. The complex RI of the aerosols was retrieved by extinction measurements of several particle sizes (175 to $325 \mathrm{~nm}$ with $25 \mathrm{~nm}$ steps), assuming sphericity and similar composition for each selected diameter, and by fitting a Mie curve to the measured extinction cross sections at each specific wavelength. ${ }^{28,51-55}$ In brief, dried particles from the OFR were sampled after a VOC denuder. Particles were size-selected with an AAC, thus yielding a monodispersed particle size distribution. The monodispersed particles were directed into a photoacoustic (404 nm)-cavity ring-down spectrometer (404 nm)-broadband cavity-enhanced spectrometer (PASCRDS-BBCES) system and counted by a condensation particle counter (CPC, model 3752, TSI). The retrieval algorithm was limited to searching for $n \geq 1$ and $k \geq 0$.

\section{RESULTS AND DISCUSSION}

\subsection{Bulk Characterization of the $\mathrm{BSOA}_{\mathrm{NO}_{3}}$ Using HR-}

Tof-AMS. The oxidation reactions of isoprene and terpenes with $\mathrm{NO}_{3}$. occur almost exclusively by the addition of the $\mathrm{NO}_{3} \cdot$ to the $\mathrm{C}=\mathrm{C}$ double bond to form the most substituted nitrooxyalkyl radical. ${ }^{56,57}$ This nitrooxyalkyl radical reacts with $\mathrm{O}_{2}$ to create $\beta$-nitrooxyperoxy radical $\left(\mathrm{RO}_{2} \cdot\right)$ that further reacts with $\mathrm{NO}_{3} \cdot$, hydroperoxyl radical $\left(\mathrm{HO}_{2} \cdot\right)$, and another $\mathrm{RO}_{2}$. to produce hydroxyl nitrate, carbonyl nitrate, and nitrooxyperoxide. ${ }^{41}$ Large $\mathrm{RO}_{2} \cdot$ species can undergo autoxidation to produce highly oxidized molecules ${ }^{58-61}$ or produce dimers through bimolecular reactions with another $\mathrm{RO}_{2} \cdot{ }^{62,63}$ The HR-Tof-AMS data of the SOA generated in this study show a high intensity $(4.1-24.7 \%)$ at $\mathrm{m} / z 43\left(\mathrm{C}_{2} \mathrm{H}_{3} \mathrm{O}^{+}\right.$, characteristic fragment of carbonyl compounds) and contain a considerable fraction $(1.8-3.9 \%)$ of nitrogen-containing fragments $\left(\mathrm{C}_{x} \mathrm{H}_{y} \mathrm{O}_{i} \mathrm{~N}^{+}\right)$(Figure 1 and Table $\mathrm{S} 1$ ), indicating that the production of carbonyls and ONs is favored during the $\mathrm{NO}_{3}$. oxidation of BVOCs, which is consistent with the known oxidation mechanism. ${ }^{41}$ Weak mass peaks at $\mathrm{m} / z 44\left(\mathrm{CO}_{2}^{+}\right)$ from carboxyl/acyl peroxide groups ${ }^{64}$ were detected (0.6$4.0 \%$, Figure 1 and Table S1). These mass spectra of the SOA from the $\mathrm{NO}_{3}$. oxidation of BVOCs consist of a prominent $\mathrm{C}_{x} \mathrm{H}_{y}{ }^{+}$ion signal (an indication of the hydrocarbon-like organic aerosol (HOA)) and $\mathrm{C}_{x} \mathrm{H}_{y} \mathrm{O}^{+}$ion signals (a sign of carbonyl compounds), whereas the signature of higher-generation oxidation products (indicated by $\mathrm{C}_{x} \mathrm{H}_{y} \mathrm{O}_{z}{ }^{+}$ions) is observed at trace levels. These features are common in the ambient semivolatile oxygenated organic aerosols (SV-OOAs) or LOOOAs. $^{23,64-67}$

Nitrogen-containing ions $\left(\mathrm{C}_{x} \mathrm{H}_{y} \mathrm{O}_{i} \mathrm{~N}_{j}^{+}, \mathrm{NO}^{+}\right.$, and $\left.\mathrm{NO}_{2}^{+}\right)$ comprise $\sim 17 \%(11-25 \%)$ of the combined organic and nitrate signals and are detected mainly as $\mathrm{NO}^{+}$and $\mathrm{NO}_{2}{ }^{+}$ions (7-23\%) with a small amount of $\mathrm{C}_{x} \mathrm{H}_{y} \mathrm{O}_{i} \mathrm{~N}_{j}^{+}$ions (2-4\%) for all of the generated $\mathrm{BSOA}_{\mathrm{NO}_{3}}$. In this study, the reactions were performed under dry conditions $(\mathrm{RH}<5 \%)$, and no ammonium was detected in the SOA; therefore, nitrogencontaining fragments are predominantly from ONs. The characteristic fragment intensity ratio of $\mathrm{NO}^{+} / \mathrm{NO}_{2}{ }^{+}$has been frequently used as an indicator of particulate organic nitrate, as this ratio is much higher for organic nitrates (usually assumed to be 10) than the ratio measured for inorganic nitrates, as determined by measuring it for $\mathrm{NH}_{4} \mathrm{NO}_{3}{ }^{19,68-70}$ The $\mathrm{NO}^{+} / \mathrm{NO}_{2}{ }^{+}$ratios in the mass spectra of the SOA ranged 


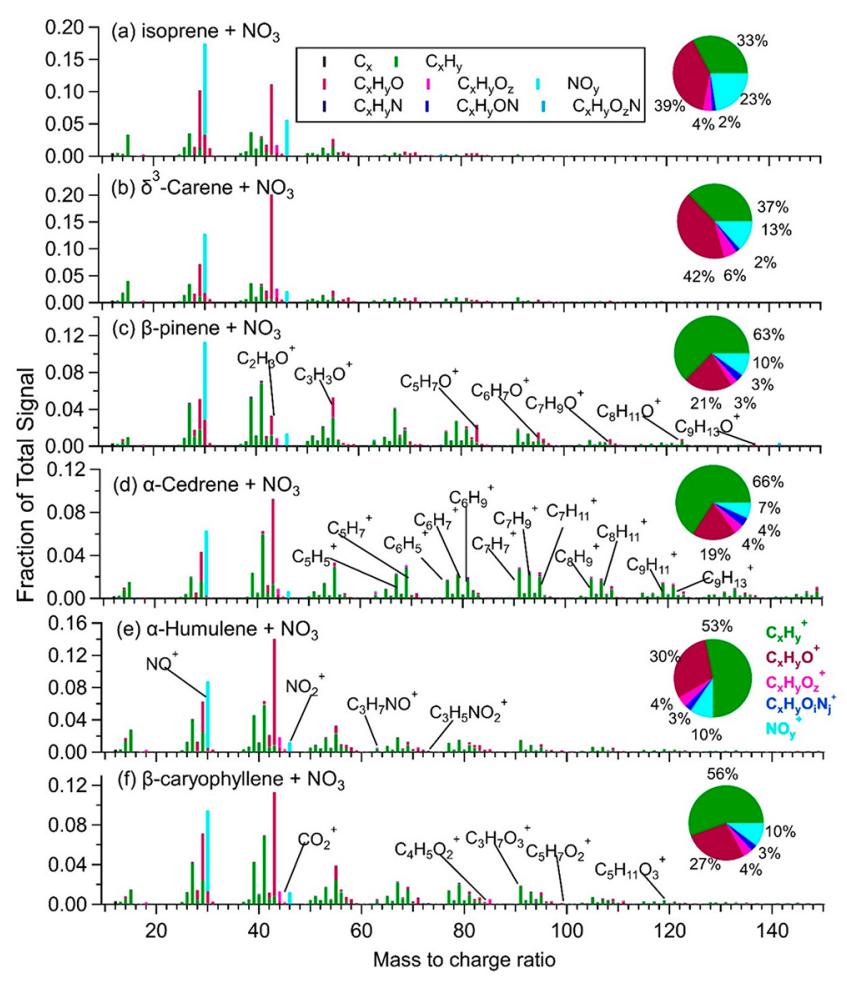

Figure 1. Chemical composition of the $\mathrm{BSOA}_{\mathrm{NO}_{3}}$ measured by HRTof-AMS. The pie charts show the bulk chemical information, including organic-related fragments (grouped as $\mathrm{C}_{x} \mathrm{H}_{y}^{+}, \mathrm{C}_{x} \mathrm{H}_{y} \mathrm{O}^{+}$, $\mathrm{C}_{x} \mathrm{H}_{y} \mathrm{O}_{z}^{+}, \mathrm{C}_{x} \mathrm{H}_{y} \mathrm{O}_{i} \mathrm{~N}_{j}^{+}$, and $\mathrm{NO}_{y}^{+}$, where $x, y, z$, and $\left.j \geq 1, i \geq 0\right)$. Large portions of hydrocarbon-like (indicated by $\mathrm{C}_{x} \mathrm{H}_{y}^{+}$), less oxygenated fragments (indicated by $\mathrm{C}_{x} \mathrm{H}_{y} \mathrm{O}^{+}$), and nitrogen-containing fractions (indicated by $\mathrm{C}_{x} \mathrm{H}_{y} \mathrm{O}_{i} \mathrm{~N}_{j}^{+}$and $\mathrm{NO}_{y}^{+}$) are observed. The boxed legend is for the mass spectra, whereas the bold legend belongs to the pie chart. Ions of $\mathrm{C}_{x} \mathrm{H}_{y} \mathrm{~N}, \mathrm{C}_{x} \mathrm{H}_{y} \mathrm{ON}$, and $\mathrm{C}_{x} \mathrm{H}_{y} \mathrm{O}_{z} \mathrm{~N}$ in the mass spectra are categorized to $\mathrm{C}_{x} \mathrm{H}_{y} \mathrm{O}_{i} \mathrm{~N}_{j}^{+}$in the pie chart.

from 4.0 to 9.6 in this study, comparable to those observed for the SOA from the $\mathrm{NO}_{3}$. oxidation of isoprene, $\beta$-pinene, $\delta^{3}$ carene, and limonene. ${ }^{15,70-74}$ These ratios are higher than those of inorganic nitrates (2.2 for $\mathrm{NH}_{4} \mathrm{NO}_{3}$ ), further supporting the formation of ON products. The N/C ratio of the SOA formed from the $\beta$-pinene $+\mathrm{NO}_{3}$ reaction averaged 0.077 , which is in good agreement with the reported values of 0.070 to 0.076 in previous studies. ${ }^{15,74,75}$

3.2. Complex Refractive Index of the Generated $\mathrm{BSOA}_{\mathrm{NO}_{3}}$. Only a few previous studies have investigated the RI of the SOA produced from $\mathrm{NO}_{3}$. oxidation. ${ }^{35-37}$ Figure 2 shows the $\mathrm{RI}$ of the $\mathrm{BSOA}_{\mathrm{NO}_{3}}$ across most of the solar wavelength range $(315-650 \mathrm{~nm})$. A comparison of our results and the literature data is shown in Figure S5. To the best of our knowledge, this is the first set of wavelength-resolved RI results for the $\mathrm{BSOA}_{\mathrm{NO}_{3}}$ over such a wide wavelength range based on online measurements. The real part of the RI $(n)$ of the $\mathrm{BSOA}_{\mathrm{NO}_{3}}$ in this study varied between 1.43 and 1.55. The real RI for the generated SOA exhibits a slight spectral dependence with $n$ values that decrease with increasing wavelength. This weak wavelength dependence is similar to that observed for the SOA from the $\mathrm{OH}$. oxidation of $\beta$ pinene $^{33}$ and the ozonolysis of monoterpenes. ${ }^{31}$ Moreover, the results from the BBCES are consistent with those from an independent CRD measurement. The value of $n$ at $404 \mathrm{~nm}$ for

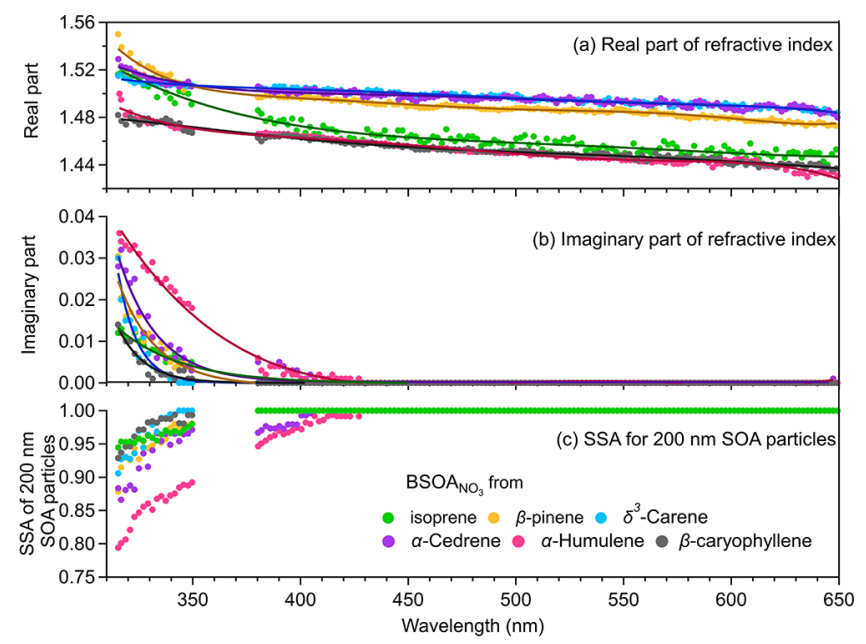

Figure 2. Wavelength-dependent optical properties of the $\mathrm{BSOA}_{\mathrm{NO}_{3}}$. The real part (a) and imaginary part (b) decrease with increasing wavelength. The $k$ is observed only at the deep UV wavelength range. (c) Single scattering albedo (SSA) values were calculated for $200 \mathrm{~nm}$ spherical particles. Data for $\beta$-pinene, $\beta$-caryophyllene, and the $\alpha$ humulene-derived SOA are taken from experiments with a $\mathrm{N}_{2} \mathrm{O}_{5}$ / VOC ratio of $1.2,10.7$, and 8.8 , respectively. The results of isoprene, $\delta^{3}$-carene, and $\alpha$-cedrene are obtained under a $\mathrm{N}_{2} \mathrm{O}_{5} / \mathrm{VOC}$ ratio of $1.3,1.9$, and 5.8 , respectively.

the SOA of isoprene $+\mathrm{NO}_{3}(1.472 \pm 0.007)$ from our study is similar to those $\left(1.455_{-0.023}^{+0.023}\right.$ to $\left.1.468_{-0.027}^{+0.025}\right)$ measured for the SOA from isoprene $+\mathrm{O}_{3}+\mathrm{NO}_{x}$ in the presence/absence of sulfur dioxides. ${ }^{34}$ However, the values of $n$ at $532 \mathrm{~nm}$ for the SOA from $\beta$-pinene $+\mathrm{NO}_{3}(1.486 \pm 0.001)$ and $\delta^{3}$-carene + $\mathrm{NO}_{3}(1.493 \pm 0.001)$ are much lower than that (1.578) of limonene $+\mathrm{NO}_{3}$, ${ }^{35}$ indicating that the real $\mathrm{RI}$ of the $\mathrm{BSOA}_{\mathrm{NO}_{3}}$ highly depends on the VOC precursor. Varma et al. ${ }^{37}$ studied the $\mathrm{NO}_{3}$-initiated oxidation of $\beta$-pinene under dry conditions using the BBCES at the SAPHIR atmospheric simulation chamber. They determined an $n$ value of $1.61 \pm 0.03$ between 655 and $687 \mathrm{~nm}$, assuming no absorption. In our study, the wavelength range was limited to $650.7 \mathrm{~nm}$. The $n$ value for the $\mathrm{BSOA}_{\mathrm{NO}_{3}}$ from $\beta$-pinene at this wavelength is $1.474( \pm 0.001)$, which is substantially lower than those from the SAPHIR experiments. The SAPHIR experiments were conducted at much lower VOC levels ( $<18$ ppbv) and for a longer period $(\sim 1 \mathrm{~h})$ compared with this study (>40 ppbv, $162 \mathrm{~s})$. These differences in the experimental conditions may lead to a differences in the SOA formation that will further affect the real RI.

Previous studies determined a near-zero imaginary part of the RI (imaginary $\mathrm{RI}, k$ ) of the SOA produced by the photooxidation/ozonolysis/OH oxidation of BVOCs under $\mathrm{NO}_{x}$-free conditions for the atmospherically relevant wavelength region $(\lambda>300 \mathrm{~nm})$, especially in the visible range. ${ }^{3,27,32,33,51}$ In this study, we determined the optical properties of the $\mathrm{BSOA}_{\mathrm{NO}_{3}}$ in the short $\mathrm{UV}$ wavelength range $(315-350 \mathrm{~nm})$ using our unique UV channel $\left(\mathrm{BBCES}_{\mathrm{UV}}\right)$. Most of the generated SOA absorbs slightly in the deep UVA wavelength range, and $k$ decreases with increasing wavelength (Figure 2 and Table S5), which is the typical behavior of $\mathrm{BrC}$. The $k$ values obtained from all of the oxidation experiments are 0.003 to 0.046 at $316 \mathrm{~nm}$ and 0.001 to 0.039 at $330 \mathrm{~nm}$. Above $390 \mathrm{~nm}$, very weak light absorption was detected, in line with 


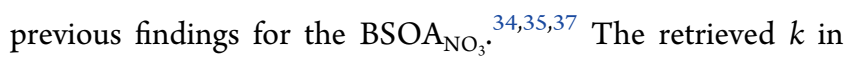
the UV range is similar to that observed for the SOA produced by the photooxidation of aromatic compounds (e.g., toluene and $m$-xylene) and higher than that of the SOA generated by the ozonolysis of $\alpha / \beta$-pinene. ${ }^{31,76}$ The $k$ of the $\mathrm{BSOA}_{\mathrm{NO}_{3}}$ obtained in this study is much lower than that for the ammonia-aged biogenic SOA ${ }^{51}$ and biomass burning aerosols (Figure S5). ${ }^{38,77-80}$ Recently, the optical properties of the SOA from the $\mathrm{NO}_{3}$. oxidation of unsaturated heterocyclic VOCs were studied. ${ }^{81}$ The values of $k$ for pyrrole and the thiophene-derived SOA range between 0.002 and 0.017 at 375 $\mathrm{nm}$. These values are higher than those measured for the $\mathrm{BSOA}_{\mathrm{NO}_{3}}$ in this study. Previous studies for isoprene $+\mathrm{NO}_{3}$ have reported an $k$ value of 0.0001 at $375 \mathrm{~nm}$ when sulfur dioxide is added during the oxidation process. ${ }^{34}$ In this study, the $k$ value of the SOA from isoprene $+\mathrm{NO}_{3}$ is $0.005( \pm 0.006)$ at $349.4 \mathrm{~nm}$, and it is essentially zero in the longer wavelength range $(380-650 \mathrm{~nm})$. The imaginary $\mathrm{RI}$ of the $\mathrm{BSOA}_{\mathrm{NO}_{3}}$ from $\alpha$-humulene is the largest among all of the studied systems. As discussed in Sections 3.3-3.5, the absorption is controlled by the ONs in the SOA, and ONs that have a carbonyl-adjacent nitrate group exhibit stronger absorption compared with other types of ONs. The high $\mathrm{N}_{2} \mathrm{O}_{5} / \mathrm{VOC}$ ratio in the $\alpha$-humulene + $\mathrm{NO}_{3} \cdot$ experiment (8.8) favors the formation of ONs. Moreover, $\alpha$-humulene has three substituted $\mathrm{C}=\mathrm{C}$ bonds (two, one, one, one, and two for isoprene, $\beta$-pinene, $\delta^{3}$-carene, $\alpha$-cedrene, $\beta$-caryophyllene, respectively) that can form stable (and do not favor cyclize reactions) ONs with a carbonyl adjacent to the nitrate group. This results in a stronger absorption in the $\mathrm{BSOA}_{\mathrm{NO}_{3}}$ from $\alpha$-humulene as compared with the other types of $\mathrm{BSOA}_{\mathrm{NO}_{3}}$.

The single scattering albedo (SSA) (SSA = scattering/ extinction) is frequently used in climate models. The SSA data for the $\mathrm{BSOA}_{\mathrm{NO}_{3}}$ in this study were calculated for $200 \mathrm{~nm}$ particles based on the Mie theory using the retrieved refractive index. The SSA is 1 for all $\mathrm{BSOA}_{\mathrm{NO}_{3}}$ above $425 \mathrm{~nm}$. In the UV ranges, the SSA increases from 0.80 to 1 with increasing wavelength. These values are higher than those obtained for the SOA produced from aromatics ${ }^{32,76,82}$ and the aerosol derived from biomass burning. ${ }^{80,83}$ Overall, the $\mathrm{BSOA}_{\mathrm{NO}_{3}}$ is not a significant $\mathrm{BrC}$ contributor. However, it does absorb substantially between 280 and $300 \mathrm{~nm}$, meaning it is photochemically active in the UVA range, which likely induces condensed-phase photochemistry.

3.3. Linking Light Absorption with Chromophores. The nighttime reactions of BVOCs with $\mathrm{NO}_{3}$. lead to the formation of secondary $\mathrm{BrC}$, which absorbs at short wavelengths. Therefore, it is essential to identify the compounds that are responsible for the observed absorption. Figure 3 shows the UV-vis chromatograms at $290 \mathrm{~nm}$ (blank corrected) as detected by the ultraperformance liquid chromatography-photodiode array (UPLC-PDA) performed in parallel with heated electrospray ionization/high-resolution mass spectrometry (HESI/HRMS). We present absorption at $290 \mathrm{~nm}$ to provide a better signal-to-noise ratio. Significant absorption was observed at a retention time (RT) of $9.0 \mathrm{~min}$ in the $\mathrm{BSOA}_{\mathrm{NO}_{3}}$ from $\beta$-pinene. High abundances of monomers and dimers with formulas of $\mathrm{C}_{10} \mathrm{H}_{13-17} \mathrm{O}_{5,6}$ and $\mathrm{C}_{19,20} \mathrm{H}_{28,31} \mathrm{~N}_{1,2} \mathrm{O}_{10-12}$ were found in the HESI/HRMS chromatograms. The UV-vis absorption peak at $\sim 290 \mathrm{~nm}$,

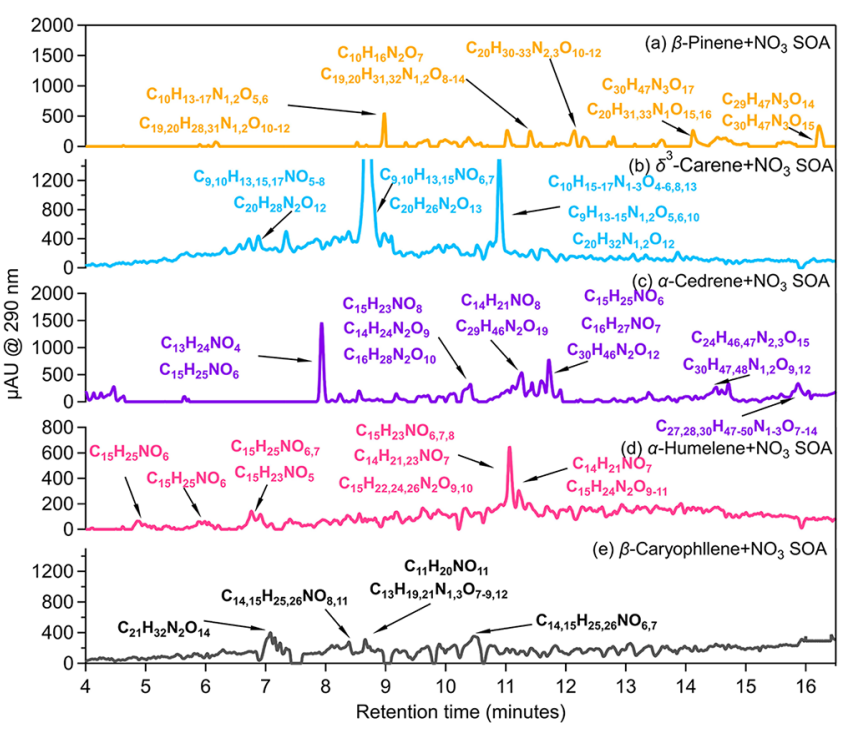

Figure 3. Possible formulas of absorbing compounds detected in the $\mathrm{BSOA}_{\mathrm{NO}_{3}}$ by HPLC-PDA-HESI/HRMS. ONs are responsible for the absorption peaks observed by the PDA. Data for the $\beta$-pinene-, $\beta$ caryophyllene-, and $\alpha$-humulene-derived SOAs are taken from experiments with a $\mathrm{N}_{2} \mathrm{O}_{5} / \mathrm{VOC}$ ratio of $1.2,10.7$, and 8.8, respectively.

which is the absorption feature of carbonyls or ONs, ${ }^{84,85}$ is coincident with the result from HR-Tof-AMS in that large amounts of carbonyls or ONs were produced in the $\mathrm{BSOA}_{\mathrm{NO}_{3}}$. We extracted the wavelength-dependent absorption spectra for the chromatograms shown in Figure 3 and compared them to those of typical nitrate-containing organics and carbonyls (Figure S3). The spectra obtained from the $\mathrm{BSOA}_{\mathrm{NO}_{3}}$ showed an absorption maximum at $\sim 290 \mathrm{~nm}$ within the wavelength range of $240-340 \mathrm{~nm}$, which is similar to that of carbonyls and organic nitrates. This further supports the formula's assignment from the mass spectrometer and illustrates that carbonyl ONs are responsible for light absorption, although it is not possible to differentiate the contribution of each compound due to their overlapping elution times in the UPLC. In the other types of $\mathrm{BSOA}_{\mathrm{NO}_{3}}$ studied, the light absorption was attributed to the most abundant $\mathrm{ON}$ dimers and oligomers. Interestingly, two $\mathrm{C}_{15} \mathrm{H}_{25} \mathrm{NO}_{6}$ isomers in the $\mathrm{BSOA}_{\mathrm{NO}_{3}}$ from $\alpha$ humulene are potential light -absorbers, whereas only one of the four isomers of $\mathrm{C}_{15} \mathrm{H}_{24} \mathrm{~N}_{2} \mathrm{O}_{9}$, the dominant species in the mass spectra, showed detectable light absorption (Figure S6). This indicates that different isomers can have quite different lifetimes regarding atmospheric photolysis. Only a few lightabsorbing species with weak absorption were identified in the $\mathrm{BSOA}_{\mathrm{NO}_{3}}$ from $\beta$-caryophyllene (Figure 3e), consistent with the result from the online $\mathrm{BBCES}$ measurements.

3.4. Influence of the $\mathrm{N}_{2} \mathrm{O}_{5} / \mathrm{VOC}$ Ratio on the Chemical Composition and RI. Faxon et al. ${ }^{14}$ measured the chemical composition of the SOA from the $\mathrm{NO}_{3}$. oxidation of limonene using a high-resolution time-of-flight chemical ionization mass spectrometer combined with a filter inlet for gases and aerosols to measure. They found that the chemical composition of the SOA (e.g., thermally unstable dimers) changed dramatically with the initial $\mathrm{N}_{2} \mathrm{O}_{5} /$ limonene ratio. In this study, we produced the SOA from $\beta$-pinene, $\beta$-caryophyllene, and $\alpha$ humulene at different $\mathrm{N}_{2} \mathrm{O}_{5} /$ VOC ratios (Table S1). Under 
higher initial $\mathrm{N}_{2} \mathrm{O}_{5}$ /VOC ratios, more $\mathrm{NO}_{3}$. was involved in the reaction with BVOCs and intermediates or taken up by particles to react with organic species (Table S4). Thus the SOA contains more nitrate groups, as was observed by HRTof-AMS (Figure 4a). This was also confirmed by the AMS
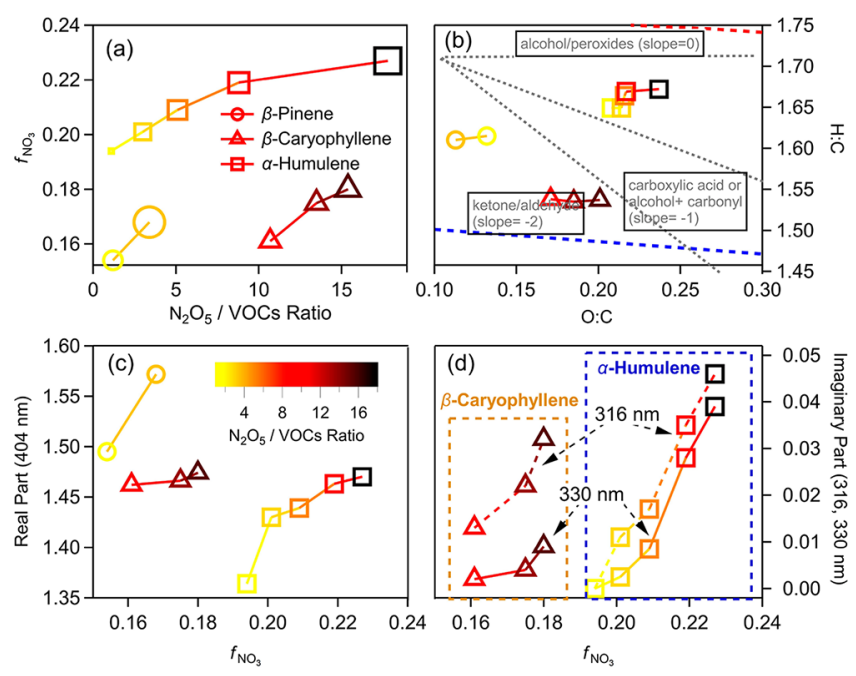

Figure 4. Influence of the initial $\mathrm{N}_{2} \mathrm{O}_{5} / \mathrm{VOC}$ ratio on the chemicalphysical properties of the $\mathrm{BSOA}_{\mathrm{NO}_{3}}$ from $\beta$-pinene (O), $\beta$ caryophyllene $(\triangle)$, and $\alpha$-humulene $(\square)$. The symbol's color indicates the initial $\mathrm{N}_{2} \mathrm{O}_{5} / \mathrm{VOC}$ ratio, and the symbol's size in panel a represents the effective particle density. With the increasing initial $\mathrm{N}_{2} \mathrm{O}_{5} /$ VOC ratio, the nitrate fraction $\left(f_{\mathrm{NO}_{3}}\right)$ and the particle's effective density (a), the elemental ratios (b), the real refractive index at $404 \mathrm{~nm}(\mathrm{c})$, and the imaginary refractive index at 316 and $330 \mathrm{~nm}$ (d) increased.

fragment analysis, where the contribution of $\mathrm{NO}_{y}^{+}$, which originated from ONs in the SOA, increased with the initial $\mathrm{N}_{2} \mathrm{O}_{5} /$ VOC (Figure S7). The studied terpenes have $\mathrm{C}=\mathrm{C}$ double bonds with more than one ring. Thus the firstgeneration oxidation products from $\mathrm{NO}_{3} \cdot$-initiated oxidation may still contain a $\mathrm{C}=\mathrm{C}$ double bond that can further react with $\mathrm{NO}_{3} \cdot$ to generate products with multiple nitrate groups. The RI of the SOA also changed under different initial $\mathrm{N}_{2} \mathrm{O}_{5}$ / VOC ratios, with a higher real part and imaginary part of the $\mathrm{RI}$ under higher $\mathrm{N}_{2} \mathrm{O}_{5}$ /VOC ratios (Figure $\mathrm{S} 8$ ).

Both the $\mathrm{H} / \mathrm{C}$ and $\mathrm{O} / \mathrm{C}$ ratios, the particle effective density, and the nitrate fraction $\left(f_{\mathrm{NO}_{3}}\right)$ in the SOA observed by HRTof-AMS increased with increasing $\mathrm{N}_{2} \mathrm{O}_{5}$ /VOC ratios, as shown in Figure $4 b-d$, confirming the functionalization (e.g., $-\mathrm{OH}$ or $-\mathrm{OOH}$ addition to the $\mathrm{C}=\mathrm{C}$ bonds) during the oxidation by $\mathrm{NO}_{3}$. The Lorentz-Lorenz relationship ( $\left.\frac{\left(n^{2}-1\right)}{\left(n^{2}+2\right)}=\frac{\alpha \rho}{3 \mathrm{MW}}\right)$ correlates the real $\mathrm{RI}(n)$ to the mean polarizability $(\alpha)$, the particle effective density $(\rho)$, and the average molecular weight (MW) of the SOA. The mean polarizability can be estimated by the additive group contribution method. ${ }^{86,87}$ The enhanced functionalization under higher $\mathrm{N}_{2} \mathrm{O}_{5} / \mathrm{VOC}$ ratios significantly increases the $\mathrm{H} / \mathrm{C}$ and $\mathrm{O} / \mathrm{C}$ ratios and the nitrate fraction and therefore increases the mean polarizability of the SOA, in combination with the increased effective density, causing an increase in the real $\mathrm{RI}$ of the $\mathrm{BSOA}_{\mathrm{NO}_{3}}$ under higher $\mathrm{N}_{2} \mathrm{O}_{5} / \mathrm{VOC}$ ratios. HPLC-PDA-HESI/HRMS results have revealed that ONs are responsible for the observed light absorption. Under higher initial $\mathrm{N}_{2} \mathrm{O}_{5} / \mathrm{BVOC}$ ratio conditions, the $f_{\mathrm{NO}_{3}}$ of the produced SOA is higher, indicating more abundant ONs in the SOA. As a result, a larger imaginary $\mathrm{RI}$ is expected. In urban conditions, the $\mathrm{NO}_{3}$. production rate is enhanced, whereas BVOC emissions can be relatively lower. Thus the produced BSOA may show more light-absorbing ability over and downwind of cities. $^{88}$

3.5. Optical Properties Evolution upon Photochemical Aging. Chemical characterization shows that ONs comprise a significant fraction of the light-absorbing $\mathrm{BSOA}_{\mathrm{NO} 3}$. Therefore, it is important to understand how the optical properties change during daytime $\mathrm{OH}$-dominated oxidation. To address this important question, we exposed the monoterpene ( $\beta$-pinene) and sesquiterpene ( $\alpha$-humulene) $\mathrm{BSOA}_{\mathrm{NO}_{3}}$ to an equivalent of 1 day of aging by $\mathrm{OH} \cdot$ in a PAM OFR. As shown in Table S6, a slight decrease in the $f_{\mathrm{NO}_{3}}$ was observed ( 0.201 to 0.196 and 0.206 to 0.192 for $\beta$-pinene and $\alpha$-humulene, respectively), indicating that the particulate ONs are resistant to $\mathrm{OH}$ - aging, which is consistent with previous findings for the $\mathrm{BSOA}_{\mathrm{NO}_{3}}$ from $\beta$-pinene. ${ }^{15}$ For the $\mathrm{BSOA}_{\mathrm{NO}_{3}}$ from $\beta$-pinene, whereas the $\mathrm{O} / \mathrm{C}$ ratio of the $\mathrm{OH}$ aged SOA increased slightly, the $\mathrm{H} / \mathrm{C}$ ratio decreased, indicating the $\mathrm{H}$-abstraction reaction during $\mathrm{OH}$ - aging. Upon $\mathrm{OH}$ - aging of the $\mathrm{BSOA}_{\mathrm{NO}_{3}}$ from $\alpha$-humulene, a slight increase in the $\mathrm{H} / \mathrm{C}(\sim 0.005)$ and $\mathrm{O} / \mathrm{C}$ ratios (by 0.022) was observed, indicating functionalization $(\mathrm{OH} \cdot$ addition), possibly due to the remaining unsaturated $\mathrm{C}=\mathrm{C}$ bonds in the SOA, which favors the addition of functional groups.

In Figure 5, we show the RI evolution from photochemical aging. The real part at 315.3, 330.3, 349.3, 404.4, and $599.8 \mathrm{~nm}$ and the imaginary part at $315.3,330.3$, and $349.3 \mathrm{~nm}$ are highlighted. For the $\mathrm{BSOA}_{\mathrm{NO}_{3}}$ from $\beta$-pinene, the real RI

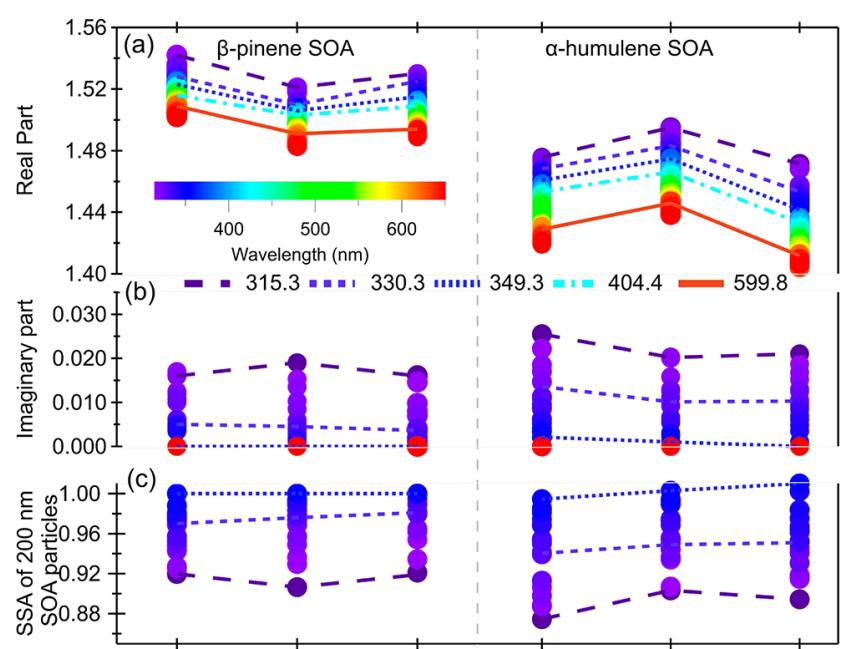

$\mathrm{NO}_{3}$ oxidation $\mathrm{OH}$ aging Photolysis $\mathrm{NO}_{3}$ oxidation $\mathrm{OH}$ aging Photolysis

Figure 5. Modification of the RI and single scattering albedo (SSA) of the $\mathrm{BSOA}_{\mathrm{NO}_{3}}$ by $\mathrm{OH}$ - aging and photolysis. (A,B) Evolution of the broadband RIs of the BSOA from the $\mathrm{NO}_{3}$. oxidation of $\beta$-pinene and $\alpha$-humulene after $24 \mathrm{~h}$ of equivalent ambient $\mathrm{OH}$ - exposure time or $1.7 \times 10^{14}$ photons $\mathrm{cm}^{-2}$ photolysis at $254 \mathrm{~nm}$. (C) SSA transformations for $200 \mathrm{~nm}$ SOA particles at UV wavelengths $(315-349 \mathrm{~nm})$. Changes in the RI and SSA at 315.3 (purple), 330.3 (light blue), 349.3 (blue), 404.4 (cyan), and 599.8 (red) are displayed as lines. 
decreased slightly when the SOA was processed with photolysis and photochemical aging, whereas no significant change in the imaginary RI was observed. For the $\mathrm{BSOA}_{\mathrm{NO}_{3}}$ from $\alpha$-humulene, the real $\mathrm{RI}$ of the SOA increased during $\mathrm{OH}$ - aging, and it is resilient to photolysis. The imaginary RI decreased during both the photolysis and the $\mathrm{OH}$ - aging process. Therefore, the SSA for $200 \mathrm{~nm}$ particles increased. For the $\mathrm{BSOA}_{\mathrm{NO}_{3}}$ from $\beta$-pinene, the real RI decreased slightly, possibly due to the loss of ON moieties that efficiently scatter light. The absorption of the SOA is linked to specific ONs (e.g., $\mathrm{C}_{10} \mathrm{H}_{13-17} \mathrm{NO}_{5,6}$ and $\mathrm{C}_{19,20} \mathrm{H}_{28,31} \mathrm{~N}_{1,2} \mathrm{O}_{10-12}$ ), as shown in Figure 3. Because of the deactivation of the $\mathrm{C}-\mathrm{H}$ bonds by adjacent functional groups, these highly functionalized ONs have fewer $\mathrm{H}-\mathrm{C}$ bonds available for $\mathrm{H}$ abstraction by $\mathrm{OH}$. oxidation, making them more resistant than less functionalized compounds. Thus the imaginary RI does not significantly change during the $\mathrm{OH}$ - aging experiments. Moreover, the interaction between the carbonyl and the nitrate functional groups will induce strong light absorption. A previous study by Draper et al. has found that ONs with a carbonyl adjacent to the nitrate group can be produced through left scission reactions of nitroxyalkoxyl radicals that are produced by the $\mathrm{NO}_{3}$. radical oxidation of unsaturated VOCs. ${ }^{13}$ The $\beta$-pinene molecule has only one substituted $\mathrm{C}=\mathrm{C}$ double bond to form products with a carbonyl adjacent to the nitrate group. Moreover, these products rapidly cyclize and further react in particles to form acetal heterodimers and heterotrimers, leading to a loss of the carboxyl adjacent to the nitrate groups (Figure S9). ${ }^{57}$ Thus no significant strong absorbing species will be produced in the $\mathrm{BSOA}_{\mathrm{NO}_{3}}$ from $\beta$-pinene. Moreover, in the $\mathrm{ON}$ produced from the $\mathrm{NO}_{3}$. oxidation of $\beta$-pinene, the carbonyl group is further away from the nitrate functional group, or there is a hydroxyl functional group adjacent the nitrate functional group. ${ }^{57,74}$ The lack of interaction between carbonyl and nitrate functional groups seems to induce negligible light absorption. This weak light-absorbing ability of the $\mathrm{BSOA}_{\mathrm{NO}_{3}}$ also suggests that its photolysis will be insignificant, which is in line with the previous finding that the $\mathrm{ON}$ fraction of the $\mathrm{BSOA}_{\mathrm{NO}_{3}}$ from $\beta$-pinene was resistant to photochemical aging. ${ }^{15}$ As a result of the significant decrease in the real part and the small change in the imaginary part upon $\mathrm{OH}$ - aging, the SSA decreased in the UVA range, indicating that the aged SOA can have a relatively stronger warming effect. The $\alpha$-humulene molecule has three substituted $\mathrm{C}=\mathrm{C}$ double bonds that form products with a carbonyl adjacent to the nitrate group. The carbonyls adjacent to the nitrate groups are further away from the hydroxyl group, which does not favor the cyclize process, stabilizing in the particle phase. The coupling of these two functional groups in the $\mathrm{BSOA}_{\mathrm{NO}_{3}}$ from $\alpha$-humulene can enhance the light absorption, as confirmed by the relatively high imaginary RI, resulting in the higher photolysis efficiency of ONs. The photolysis proceeds by releasing $\mathrm{NO}_{2}$ and forming compounds with fewer or even no nitrate groups. Photolysis at UVA will also decompose carbonyls, which would have an additional photobleaching effect. Thus upon photolysis, both the real part and the imaginary part of the RI decreased, resulting in an overall increase in the SSA. On the basis of the change in absorption, we calculated the photolysis lifetime of absorbing $\mathrm{ON}$ in the $\mathrm{BSOA}_{\mathrm{NO}_{3}}$ to be $6.2 \mathrm{~h}$ (Text S3), assuming no phase separation, which may affect the aging. Assuming no synergetic effect between photolysis and $\mathrm{OH} \cdot$ aging and excluding the photolysis-induced decrease in absorption, the $\mathrm{OH}$ - aging also bleached the particles with a lifetime of 38.8 days. For the $\alpha$-humulene-derived $\mathrm{BSOA}_{\mathrm{NO}_{3}}$, bleaching by photochemical aging (including $\mathrm{OH} \cdot$ aging and photolysis) is governed by photolysis, and the lifetime is $\sim 6 \mathrm{~h}$. These results from the $\beta$ pinene and $\alpha$-humulene aging experiments indicate that the effect of photochemical aging on the optical properties (refractive index and SSA) of the $\mathrm{BSOA}_{\mathrm{NO}_{3}}$ largely depends on the specific chemical nature of the ONs and their precursors, leading to a more complicated picture than just "bleaching" or "browning".

\section{ATMOSPHERIC IMPLICATIONS}

The study provides the chemical composition and optical properties of the SOA produced during the $\mathrm{NO}_{3}$. oxidation of terpenoids. The BBCES-CRD measurements show that the nighttime reactions studied here form $\mathrm{BrC}$, which weakly absorbs light in the UVA range. According to the framework recently introduced by Saleh et al., ${ }^{89}$ the produced $\mathrm{BSOA}_{\mathrm{NO}_{3}}$ falls into the category of very weakly absorptive $\mathrm{BrC}$. The UPLC-PDA-HRMS analysis confirmed that ONs are responsible for light absorption. In urban and suburban areas that are affected by anthropogenic pollution and high BVOC emissions, the high $\mathrm{NO}_{x}$ and $\mathrm{O}_{3}$ promote $\mathrm{NO}_{3} \cdot$ production. This could also result in a high $\mathrm{NO}_{3}$. $/$ VOC ratio, which favors $\mathrm{BrC}$ that contains a high fraction of ONs. Although the light absorption of the $\mathrm{BSOA}_{\mathrm{NO}_{3}}$ is weak, the SOA formation from the nighttime $\mathrm{NO}_{3}$. oxidation of BVOCs is efficient, especially in regions where massive anthropogenic emissions mix with BVOCs. Therefore, the $\mathrm{BSOA}_{\mathrm{NO}_{3}}$ can have a measurable impact on the aerosol UVA absorption, which could further affect the climate and air quality on a regional scale.

The $\mathrm{BSOA}_{\mathrm{NO}_{3}}$ from $\alpha$-humulene has an equivalent photolysis lifetime longer than $6.2 \mathrm{~h}$ (Text S3). Because of their weak light-absorbing properties, the photolysis of the ONs in the $\beta$-pinene $\mathrm{BSOA}_{\mathrm{NO}_{3}}$ is negligible (Figure 5). Previous studies have tested the bulk hydrolysis properties of the $\mathrm{BSOA}_{\mathrm{NO}_{3}}$ from $\alpha$ - and $\beta$-pinene. ${ }^{16,74}$ The hydrolysis lifetime varies between 0.02 and $8.8 \mathrm{~h}$, depending on the precursor VOCs, oxidant type, aerosol acidity, relative humidity, and more. Although the lifetime is short, the ON from $\mathrm{NO}_{3}$. oxidation has a low hygroscopicity, and only a small fraction $(\leq 17 \%)$ can undergo hydrolysis. ${ }^{16}$ Taking all of these factors into consideration, we suggest that the $\mathrm{BSOA}_{\mathrm{NO}_{3}}$ generated from $\beta$-pinene and $\alpha$-humulene at night would survive into the morning hours or longer and would scatter and absorb the incoming solar radiation and sequester NOx. These results indicate that $\mathrm{ONs}$ produced from the $\mathrm{NO}_{3}$. oxidation of $\beta$-pinene and $\alpha$-humulene may serve as $\mathrm{NOx}$ reservoirs or permanent $\mathrm{NO}_{x}$ sinks in the atmosphere, which is consistent with previous findings. ${ }^{15}$ We note that previous studies by $\mathrm{Nah}$ et al. have found that the particle-phase ONs in the $\mathrm{BSOA}_{\mathrm{NO}_{3}}$ from $\alpha$-pinene evaporate during photochemical aging. ${ }^{15}$ The significant photolysis of the $\alpha$-pinene $\mathrm{BSOA}_{\mathrm{NO}_{3}}$ could dramatically change its optical properties, as it behaves differently compared with the $\mathrm{BSOA}_{\mathrm{NO}_{3}}$ from $\alpha$-humulene and $\beta$-pinene. These results indicate that $\mathrm{ONs}$ in the $\mathrm{BSOA}_{\mathrm{NO}_{3}}$ produced from terpenes can serve as either temporary or 
permanent NOx sinks depending on the precursor. This finding has significant implications for $\mathrm{NO}_{x}$ and $\mathrm{O}_{3}$ budgets in areas with high emissions of monoterpenes and sesquiterpenes, such as the Southeastern United States, Northern Europe, and Southeast Asia. We suggest incorporating these processes into the current modeling strategies to improve $\mathrm{NO}_{x}$ and $\mathrm{O}_{3}$ simulations.

This study focused on the $\mathrm{ON}$ production by the $\mathrm{NO}_{3}$. oxidation of BVOCs, the optical properties of the resulting BSOA, and the evolution of their chemical and physical properties during the transition from night to day. The link between the $\mathrm{BSOA}_{\mathrm{NO}_{3}}$ formation mechanism, its chemical and physical properties, and the dynamic evolution was illustrated for both laboratory simulations and ambient aerosols. Photolysis and $\mathrm{OH}$. aging were studied here under low relative humidity (37.5\%) conditions, and the possible role of the hydrolysis of the ONs was not investigated. It is also noted that isomers with the same formula have different lightabsorbing properties and lifetimes. Therefore, isomer-specific studies may be helpful for understanding the bulk chemical and physical properties (e.g., hydrolysis and oxidation) of ONs and the SOA. Obviously, $\mathrm{RO}_{2}$. chemistry plays a role in determining the changes to the chemical and optical properties of the SOA. In this study, we focused on one set of (extreme) conditions. More detailed studies and additional modeling efforts will be conducted to understand how different $\mathrm{RO}_{2}$. regimes affect these changes and how these translate to different atmospheric chemical regimes.

\section{ASSOCIATED CONTENT}

\section{SI Supporting Information}

The Supporting Information is available free of charge at https://pubs.acs.org/doi/10.1021/acs.est.0c06838.

Additional description of methods; additional tables showing details of the SOA generation, chemical and optical results of the $\mathrm{BSOA}_{\mathrm{NO}_{3}}$, and the model simulation results in the OFR; additional figures showing the experimental setup, absorption spectra of $\mathrm{ONs}$ and carbonyls from the literature and those of compounds of interest in the $\mathrm{BSOA}_{\mathrm{NO}_{3}}$, $\mathrm{RI}$ results for the $\mathrm{BSOA}_{\mathrm{NO}_{3}}$ and from the literature, and the influence of the $\mathrm{N}_{2} \mathrm{O}_{5}$ /VOC ratio on the chemical composition and $\mathrm{RI}$ (PDF)

\section{AUTHOR INFORMATION}

\section{Corresponding Author}

Yinon Rudich - Department of Earth and Planetary Sciences, Weizmann Institute of Science, Rehovot 76100, Israel; ๑ orcid.org/0000-0003-3149-0201; Email: yinon.rudich@ weizmann.ac.il

\section{Authors}

Quanfu He - Department of Earth and Planetary Sciences, Weizmann Institute of Science, Rehovot 76100, Israel; (1) orcid.org/0000-0002-3229-8206

Sophie Tomaz - Univ Lyon, Université Claude Bernard Lyon 1, CNRS, IRCELYON, F-69626 Villeurbanne, France

Chunlin Li - Department of Earth and Planetary Sciences, Weizmann Institute of Science, Rehovot 76100, Israel; (1) orcid.org/0000-0001-9756-5638
Ming Zhu - State Key Laboratory of Organic Geochemistry and Guangdong Key Laboratory of Environmental Protection and Resources Utilization, Guangzhou Institute of Geochemistry, Chinese Academy of Sciences, Guangzhou 510640, China; University of Chinese Academy of Sciences, Beijing 100049, China; (1) orcid.org/0000-0003-2288-6271

Daphne Meidan - Department of Earth and Planetary Sciences, Weizmann Institute of Science, Rehovot 76100, Israel

Matthieu Riva - Univ Lyon, Université Claude Bernard Lyon 1, CNRS, IRCELYON, F-69626 Villeurbanne, France; (i) orcid.org/0000-0003-0054-4131

Alexander Laskin - Department of Chemistry, Purdue University, West Lafayette, Indiana 47907, United States; - orcid.org/0000-0002-7836-8417

Steven S. Brown - Chemical Sciences Division, Earth System Research Laboratory, National Oceanic and Atmospheric Administration, Boulder, Colorado 80305, United States; Department of Chemistry, University of Colorado, Boulder, Colorado 80309, United States

Christian George - Univ Lyon, Université Claude Bernard Lyon 1, CNRS, IRCELYON, F-69626 Villeurbanne, France; (1) orcid.org/0000-0003-1578-7056

Xinming Wang - State Key Laboratory of Organic Geochemistry and Guangdong Key Laboratory of Environmental Protection and Resources Utilization, Guangzhou Institute of Geochemistry, Chinese Academy of Sciences, Guangzhou 510640, China; University of Chinese Academy of Sciences, Beijing 100049, China; Center for Excellence in Urban Atmospheric Environment, Institute of Urban Environment, Chinese Academy of Sciences, Xiamen 361021, China; orcid.org/0000-0002-1982-0928

Complete contact information is available at: https://pubs.acs.org/10.1021/acs.est.0c06838

\section{Notes}

The authors declare no competing financial interest.

\section{ACKNOWLEDGMENTS}

This research was partially supported by the Israel Science Foundation (ISF) (no. 3205/19), the National Natural Science Foundation of China (NSFC) (grant no. 41961144029/41530641), the US-Israel Binational Science Foundation (BSF grant no. 2016093), the Israel Ministry of Science (Maimonides program grant no. 3-14010), and the University of Lyon through the Breakthrough project WANTED. Q.H. is supported by the Koshland Foundation and the Center for Planetary Sciences, Weizmann Institute of Science.

\section{REFERENCES}

(1) Boucher, O., Randall, D.; Artaxo, P.; Bretherton, C.; Feingold, G.; Forster, P.; Kerminen, V.-M.; Kondo, Y.; Liao, H.; Lohmann, U.; Rasch, P.; Satheesh, S. K.; Sherwood, S.; Stevens, B.; Zhang, X. Y. Clouds and Aerosols. In Climate Change 2013: The Physical Science Basis. Contribution of Working Group I to the Fifth Assessment Report of the Intergovernmental Panel on Climate Change; Cambridge University Press: New York, 2013.

(2) Seinfeld, J. H.; Bretherton, C.; Carslaw, K. S.; Coe, H.; DeMott, P. J.; Dunlea, E. J.; Feingold, G.; Ghan, S.; Guenther, A. B.; Kahn, R.; Kraucunas, I.; Kreidenweis, S. M.; Molina, M. J.; Nenes, A.; Penner, J. E.; Prather, K. A.; Ramanathan, V.; Ramaswamy, V.; Rasch, P. J.; Ravishankara, A. R.; Rosenfeld, D.; Stephens, G.; Wood, R. Improving 
our fundamental understanding of the role of aerosol-cloud interactions in the climate system. Proc. Natl. Acad. Sci. U. S. A. 2016, 113 (21), 5781-5790.

(3) Laskin, A.; Laskin, J.; Nizkorodov, S. A. Chemistry of Atmospheric Brown Carbon. Chem. Rev. 2015, 115 (10), 4335-4382.

(4) Feng, Y.; Ramanathan, V.; Kotamarthi, V. R. Brown carbon: a significant atmospheric absorber of solar radiation? Atmos. Atmos. Chem. Phys. 2013, 13 (17), 8607-8621.

(5) Hallquist, M.; Wenger, J. C.; Baltensperger, U.; Rudich, Y.; Simpson, D.; Claeys, M.; Dommen, J.; Donahue, N. M.; George, C.; Goldstein, A. H.; Hamilton, J. F.; Herrmann, H.; Hoffmann, T.; Iinuma, Y.; Jang, M.; Jenkin, M. E.; Jimenez, J. L.; Kiendler-Scharr, A.; Maenhaut, W.; McFiggans, G.; Mentel, T. F.; Monod, A.; Prevot, A. S. H.; Seinfeld, J. H.; Surratt, J. D.; Szmigielski, R.; Wildt, J. The formation, properties and impact of secondary organic aerosol: current and emerging issues. Atmos. Chem. Phys. 2009, 9 (14), 51555236.

(6) Kanakidou, M.; Seinfeld, J. H.; Pandis, S. N.; Barnes, I.; Dentener, F. J.; Facchini, M. C.; Van Dingenen, R.; Ervens, B.; Nenes, A.; Nielsen, C. J.; Swietlicki, E.; Putaud, J. P.; Balkanski, Y.; Fuzzi, S.; Horth, J.; Moortgat, G. K.; Winterhalter, R.; Myhre, C. E. L.; Tsigaridis, K.; Vignati, E.; Stephanou, E. G.; Wilson, J. Organic aerosol and global climate modelling: a review. Atmos. Chem. Phys. 2005, 5, 1053-1123.

(7) Ng, N. L.; Brown, S. S.; Archibald, A. T.; Atlas, E.; Cohen, R. C.; Crowley, J. N.; Day, D. A.; Donahue, N. M.; Fry, J. L.; Fuchs, H.; Griffin, R. J.; Guzman, M. I.; Herrmann, H.; Hodzic, A.; Iinuma, Y.; Jimenez, J. L.; Kiendler-Scharr, A.; Lee, B. H.; Luecken, D. J.; Mao, J. Q.; McLaren, R.; Mutzel, A.; Osthoff, H. D.; Ouyang, B.; PicquetVarrault, B.; Platt, U.; Pye, H. O. T.; Rudich, Y.; Schwantes, R. H.; Shiraiwa, M.; Stutz, J.; Thornton, J. A.; Tilgner, A.; Williams, B. J.; Zaveri, R. A. Nitrate radicals and biogenic volatile organic compounds: oxidation, mechanisms, and organic aerosol. Atmos. Chem. Phys. 2017, 17 (3), 2103-2162.

(8) Heald, C. L.; Jacob, D. J.; Park, R. J.; Russell, L. M.; Huebert, B. J.; Seinfeld, J. H.; Liao, H.; Weber, R. J. A large organic aerosol source in the free troposphere missing from current models. Geophys. Res. Lett. 2005, 32 (18), L18809.

(9) Goldstein, A. H.; Galbally, I. E. Known and unexplored organic constituents in the earth's atmosphere. Environ. Sci. Technol. 2007, 41 (5), 1514-1521.

(10) Edwards, P. M.; Aikin, K. C.; Dube, W. P.; Fry, J. L.; Gilman, J. B.; de Gouw, J. A.; Graus, M. G.; Hanisco, T. F.; Holloway, J.; Hübler, G.; Kaiser, J.; Keutsch, F. N.; Lerner, B. M.; Neuman, J. A.; Parrish, D. D.; Peischl, J.; Pollack, I. B.; Ravishankara, A. R.; Roberts, J. M.; Ryerson, T. B.; Trainer, M.; Veres, P. R.; Wolfe, G. M.; Warneke, C.; Brown, S. S. Transition from high- to low-NOx control of night-time oxidation in the southeastern US. Nat. Geosci. 2017, 10 (7), 490-495.

(11) Brown, S. S.; Dubé, W. P.; Peischl, J.; Ryerson, T. B.; Atlas, E.; Warneke, C.; de Gouw, J. A.; te Lintel Hekkert, S.; Brock, C. A.; Flocke, F.; Trainer, M.; Parrish, D. D.; Feshenfeld, F. C.; Ravishankara, A. R. Budgets for nocturnal VOC oxidation by nitrate radicals aloft during the 2006 Texas Air Quality Study. J. Geophys. Res. Atmos. 2011, 116 (D24), D24305.

(12) Brown, S. S.; Stutz, J. Nighttime radical observations and chemistry. Chem. Soc. Rev. 2012, 41 (19), 6405-6447.

(13) Draper, D. C.; Myllys, N.; Hyttinen, N.; Møller, K. H.; Kjaergaard, H. G.; Fry, J. L.; Smith, J. N.; Kurtén, T. Formation of Highly Oxidized Molecules from NO3 Radical Initiated Oxidation of $\Delta$-3-Carene: A Mechanistic Study. ACS Earth and Space Chem. 2019, 3 (8), 1460-1470.

(14) Faxon, C.; Hammes, J.; Le Breton, M.; Pathak, R. K.; Hallquist, $\mathrm{M}$. Characterization of organic nitrate constituents of secondary organic aerosol (SOA) from nitrate-radical-initiated oxidation of limonene using high-resolution chemical ionization mass spectrometry. Atmos. Chem. Phys. 2018, 18 (8), 5467-5481.

(15) Nah, T.; Sanchez, J.; Boyd, C. M.; Ng, N. L. Photochemical Aging of $\alpha$-pinene and $\beta$-pinene Secondary Organic Aerosol formed from Nitrate Radical Oxidation. Environ. Sci. Technol. 2016, 50 (1), 222-231.

(16) Takeuchi, M.; Ng, N. L. Chemical composition and hydrolysis of organic nitrate aerosol formed from hydroxyl and nitrate radical oxidation of $\alpha$-pinene and $\beta$-pinene. Atmos. Chem. Phys. 2019, 19 (19), 12749-12766.

(17) Lee, S.-H.; Young, L.-H.; Benson, D. R.; Suni, T.; Kulmala, M.; Junninen, H.; Campos, T. L.; Rogers, D. C.; Jensen, J. Observations of nighttime new particle formation in the troposphere. J. Geophys. Res. 2008, 113 (D10), D10210.

(18) Berkemeier, T.; Ammann, M.; Mentel, T. F.; Pöschl, U.; Shiraiwa, M. Organic Nitrate Contribution to New Particle Formation and Growth in Secondary Organic Aerosols from $\alpha$-Pinene Ozonolysis. Environ. Sci. Technol. 2016, 50 (12), 6334-6342.

(19) Kiendler-Scharr, A.; Mensah, A. A.; Friese, E.; Topping, D.; Nemitz, E.; Prevot, A. S. H.; Äijälä, M.; Allan, J.; Canonaco, F.; Canagaratna, M.; Carbone, S.; Crippa, M.; Dall Osto, M.; Day, D. A.; De Carlo, P.; Di Marco, C. F.; Elbern, H.; Eriksson, A.; Freney, E.; Hao, L.; Herrmann, H.; Hildebrandt, L.; Hillamo, R.; Jimenez, J. L.; Laaksonen, A.; McFiggans, G.; Mohr, C.; O’Dowd, C.; Otjes, R.; Ovadnevaite, J.; Pandis, S. N.; Poulain, L.; Schlag, P.; Sellegri, K.; Swietlicki, E.; Tiitta, P.; Vermeulen, A.; Wahner, A.; Worsnop, D.; $\mathrm{Wu}, \mathrm{H} .-\mathrm{C}$. Ubiquity of organic nitrates from nighttime chemistry in the European submicron aerosol. Geophys. Res. Lett. 2016, 43 (14), $7735-7744$.

(20) Lee, B. H.; Mohr, C.; Lopez-Hilfiker, F. D.; Lutz, A.; Hallquist, M.; Lee, L.; Romer, P.; Cohen, R. C.; Iyer, S.; Kurtén, T.; Hu, W.; Day, D. A.; Campuzano-Jost, P.; Jimenez, J. L.; Xu, L.; Ng, N. L.; Guo, H.; Weber, R. J.; Wild, R. J.; Brown, S. S.; Koss, A.; de Gouw, J.; Olson, K.; Goldstein, A. H.; Seco, R.; Kim, S.; McAvey, K.; Shepson, P. B.; Starn, T.; Baumann, K.; Edgerton, E. S.; Liu, J.; Shilling, J. E.; Miller, D. O.; Brune, W.; Schobesberger, S.; D'Ambro, E. L.; Thornton, J. A. Highly functionalized organic nitrates in the southeast United States: Contribution to secondary organic aerosol and reactive nitrogen budgets. Proc. Natl. Acad. Sci. U. S. A. 2016, 113 (6), 15161521.

(21) Huang, W.; Saathoff, H.; Shen, X.; Ramisetty, R.; Leisner, T.; Mohr, C. Chemical Characterization of Highly Functionalized Organonitrates Contributing to Night-Time Organic Aerosol Mass Loadings and Particle Growth. Environ. Sci. Technol. 2019, 53 (3), $1165-1174$.

(22) Ayres, B. R.; Allen, H. M.; Draper, D. C.; Brown, S. S.; Wild, R. J.; Jimenez, J. L.; Day, D. A.; Campuzano-Jost, P.; Hu, W.; de Gouw, J.; Koss, A.; Cohen, R. C.; Duffey, K. C.; Romer, P.; Baumann, K.; Edgerton, E.; Takahama, S.; Thornton, J. A.; Lee, B. H.; LopezHilfiker, F. D.; Mohr, C.; Wennberg, P. O.; Nguyen, T. B.; Teng, A.; Goldstein, A. H.; Olson, K.; Fry, J. L. Organic nitrate aerosol formation via $\mathrm{NO} 3$ + biogenic volatile organic compounds in the southeastern United States. Atmos. Chem. Phys. 2015, 15 (23), 13377-13392.

(23) Xu, L.; Guo, H.; Boyd, C. M.; Klein, M.; Bougiatioti, A.; Cerully, K. M.; Hite, J. R.; Isaacman-VanWertz, G.; Kreisberg, N. M.; Knote, C.; Olson, K.; Koss, A.; Goldstein, A. H.; Hering, S. V.; de Gouw, J.; Baumann, K.; Lee, S.-H.; Nenes, A.; Weber, R. J.; Ng, N. L. Effects of anthropogenic emissions on aerosol formation from isoprene and monoterpenes in the southeastern United States. Proc. Natl. Acad. Sci. U. S. A. 2015, 112 (1), 37-42.

(24) Fry, J. L.; Draper, D. C.; Zarzana, K. J.; Campuzano-Jost, P.; Day, D. A.; Jimenez, J. L.; Brown, S. S.; Cohen, R. C.; Kaser, L.; Hansel, A.; Cappellin, L.; Karl, T.; Hodzic Roux, A.; Turnipseed, A.; Cantrell, C.; Lefer, B. L.; Grossberg, N. Observations of gas- and aerosol-phase organic nitrates at BEACHON-RoMBAS 2011. Atmos. Chem. Phys. 2013, 13 (17), 8585-8605.

(25) Rollins, A. W.; Browne, E. C.; Min, K. E.; Pusede, S. E.; Wooldridge, P. J.; Gentner, D. R.; Goldstein, A. H.; Liu, S.; Day, D. A.; Russell, L. M.; Cohen, R. C. Evidence for NOx Control over Nighttime SOA Formation. Science 2012, 337 (6099), 1210-1212.

(26) Massoli, P.; Stark, H.; Canagaratna, M. R.; Krechmer, J. E.; Xu, L.; Ng, N. L.; Mauldin, R. L.; Yan, C.; Kimmel, J.; Misztal, P. K.; 
Jimenez, J. L.; Jayne, J. T.; Worsnop, D. R. Ambient Measurements of Highly Oxidized Gas-Phase Molecules during the Southern Oxidant and Aerosol Study (SOAS) 2013. ACS Earth Space Chem. 2018, 2 (7), 653-672.

(27) Moise, T.; Flores, J. M.; Rudich, Y. Optical Properties of Secondary Organic Aerosols and Their Changes by Chemical Processes. Chem. Rev. 2015, 115 (10), 4400-4439.

(28) Flores, J. M.; Zhao, D. F.; Segev, L.; Schlag, P.; Kiendler-Scharr, A.; Fuchs, H.; Watne, A. K.; Bluvshtein, N.; Mentel, T. F.; Hallquist, M.; Rudich, Y. Evolution of the complex refractive index in the UV spectral region in ageing secondary organic aerosol. Atmos. Chem. Phys. 2014, 14 (11), 5793-5806.

(29) Kim, H.; Barkey, B.; Paulson, S. E. Real refractive indices of $\alpha$ and $\beta$-pinene and toluene secondary organic aerosols generated from ozonolysis and photo-oxidation. J. Geophys. Res. Atmos. 2010, 115 (D24), D24212.

(30) Nakayama, T.; Sato, K.; Matsumi, Y.; Imamura, T.; Yamazaki, A.; Uchiyama, A. Wavelength Dependence of Refractive Index of Secondary Organic Aerosols Generated during the Ozonolysis and Photooxidation of alpha-Pinene. Sola 2012, 8, 119-123.

(31) Liu, P. F.; Zhang, Y.; Martin, S. T. Complex Refractive Indices of Thin Films of Secondary Organic Materials by Spectroscopic Ellipsometry from 220 to $1200 \mathrm{~nm}$. Environ. Sci. Technol. 2013, 47 (23), 13594-13601.

(32) Lambe, A. T.; Cappa, C. D.; Massoli, P.; Onasch, T. B.; Forestieri, S. D.; Martin, A. T.; Cummings, M. J.; Croasdale, D. R.; Brune, W. H.; Worsnop, D. R.; Davidovits, P. Relationship between Oxidation Level and Optical Properties of Secondary Organic Aerosol. Environ. Sci. Technol. 2013, 47 (12), 6349-6357.

(33) He, Q.; Bluvshtein, N.; Segev, L.; Meidan, D.; Flores, J. M.; Brown, S. S.; Brune, W.; Rudich, Y. Evolution of the Complex Refractive Index of Secondary Organic Aerosols during Atmospheric Aging. Environ. Sci. Technol. 2018, 52 (6), 3456-3465.

(34) Nakayama, T.; Sato, K.; Imamura, T.; Matsumi, Y. Effect of Oxidation Process on Complex Refractive Index of Secondary Organic Aerosol Generated from Isoprene. Environ. Sci. Technol. 2018, 52 (5), 2566-2574.

(35) Peng, C.; Wang, W.; Li, K.; Li, J.; Zhou, L.; Wang, L.; Ge, M. The Optical Properties of Limonene Secondary Organic Aerosols: The Role of $\mathrm{NO} 3, \mathrm{OH}$, and $\mathrm{O} 3$ in the Oxidation Processes. J. Geophys. Res.: Atmos. 2018, 123 (6), 3292-3303.

(36) Song, C.; Gyawali, M.; Zaveri, R. A.; Shilling, J. E.; Arnott, W. $\mathrm{P}$. Light absorption by secondary organic aerosol from $\alpha$-pinene: Effects of oxidants, seed aerosol acidity, and relative humidity. J. Geophys. Res. Atmos. 2013, 118 (20), 11741-11749.

(37) Varma, R. M.; Ball, S. M.; Brauers, T.; Dorn, H. P.; Heitmann, U.; Jones, R. L.; Platt, U.; Pöhler, D.; Ruth, A. A.; Shillings, A. J. L.; Thieser, J.; Wahner, A.; Venables, D. S. Light extinction by secondary organic aerosol: an intercomparison of three broadband cavity spectrometers. Atmos. Meas. Tech. 2013, 6 (11), 3115-3130.

(38) Washenfelder, R. A.; Attwood, A. R.; Brock, C. A.; Guo, H.; Xu, L.; Weber, R. J.; Ng, N. L.; Allen, H. M.; Ayres, B. R.; Baumann, K.; Cohen, R. C.; Draper, D. C.; Duffey, K. C.; Edgerton, E.; Fry, J. L.; Hu, W. W.; Jimenez, J. L.; Palm, B. B.; Romer, P.; Stone, E. A.; Wooldridge, P. J.; Brown, S. S. Biomass burning dominates brown carbon absorption in the rural southeastern United States. Geophys. Res. Lett. 2015, 42 (2), 653-664.

(39) Suarez-Bertoa, R.; Picquet-Varrault, B.; Tamas, W.; Pangui, E.; Doussin, J. F. Atmospheric Fate of a Series of Carbonyl Nitrates: Photolysis Frequencies and $\mathrm{OH}-\mathrm{Oxidation}$ Rate Constants. Environ. Sci. Technol. 2012, 46 (22), 12502-12509.

(40) Müller, J. F.; Peeters, J.; Stavrakou, T. Fast photolysis of carbonyl nitrates from isoprene. Atmos. Chem. Phys. 2014, 14 (5), 2497-2508.

(41) Atkinson, R. Gas-Phase Tropospheric Chemistry of Volatile Organic Compounds: 1. Alkanes and Alkenes. J. Phys. Chem. Ref. Data 1997, 26 (2), 215-290.

(42) Kolb, C. E.; Cox, R. A.; Abbatt, J. P. D.; Ammann, M.; Davis, E. J.; Donaldson, D. J.; Garrett, B. C.; George, C.; Griffiths, P. T.;
Hanson, D. R.; Kulmala, M.; McFiggans, G.; Poschl, U.; Riipinen, I.; Rossi, M. J.; Rudich, Y.; Wagner, P. E.; Winkler, P. M.; Worsnop, D. R.; O'Dowd, C. D. An overview of current issues in the uptake of atmospheric trace gases by aerosols and clouds. Atmos. Chem. Phys. 2010, 10 (21), 10561-10605.

(43) Gross, S.; Iannone, R.; Xiao, S.; Bertram, A. K. Reactive uptake studies of $\mathrm{NO} 3$ and $\mathrm{N} 2 \mathrm{O} 5$ on alkenoic acid, alkanoate, and polyalcohol substrates to probe nighttime aerosol chemistry. Phys. Chem. Chem. Phys. 2009, 11 (36), 7792-7803.

(44) Decker, Z.; Zarzana, K.; Coggon, M. M.; Min, K.-E.; Pollack, I.; Ryerson, T. B.; Peischl, J.; Edwards, P.; Dubé, W. P.; Markovic, M. Z.; et al. Nighttime chemical transformation in biomass burning plumes: a box model analysis initialized with aircraft observations. Environ. Sci. Technol. 2019, 53, 2529-2538.

(45) Baidar, S.; Oetjen, H.; Coburn, S.; Dix, B.; Ortega, I.; Sinreich, R; Volkamer, R. The CU Airborne MAX-DOAS instrument: vertical profiling of aerosol extinction and trace gases. Atmos. Meas. Tech. 2013, 6 (3), 719-739.

(46) Aiken, A. C.; DeCarlo, P. F.; Jimenez, J. L. Elemental analysis of organic species with electron ionization high-resolution mass spectrometry. Anal. Chem. 2007, 79 (21), 8350-8358.

(47) Canagaratna, M. R.; Jimenez, J. L.; Kroll, J. H.; Chen, Q.; Kessler, S. H.; Massoli, P.; Hildebrandt Ruiz, L.; Fortner, E.; Williams, L. R.; Wilson, K. R.; Surratt, J. D.; Donahue, N. M.; Jayne, J. T.; Worsnop, D. R. Elemental ratio measurements of organic compounds using aerosol mass spectrometry: characterization, improved calibration, and implications. Atmos. Chem. Phys. 2015, 15 (1), 253-272.

(48) Harrison, M. A. J.; Barra, S.; Borghesi, D.; Vione, D.; Arsene, C.; Iulian Olariu, R. Nitrated phenols in the atmosphere: a review. Atmos. Environ. 2005, 39 (2), 231-248.

(49) Bluvshtein, N.; Flores, J. M.; Segev, L.; Rudich, Y. A new approach for retrieving the UV-vis optical properties of ambient aerosols. Atmos. Meas. Tech. 2016, 9 (8), 3477-3490.

(50) Washenfelder, R. A.; Attwood, A. R.; Flores, J. M.; Zarzana, K. J.; Rudich, Y.; Brown, S. S. Broadband cavity-enhanced absorption spectroscopy in the ultraviolet spectral region for measurements of nitrogen dioxide and formaldehyde. Atmos. Meas. Tech. 2016, 9 (1), $41-52$.

(51) Flores, J. M.; Washenfelder, R. A.; Adler, G.; Lee, H. J.; Segev, L.; Laskin, J.; Laskin, A.; Nizkorodov, S. A.; Brown, S. S.; Rudich, Y. Complex refractive indices in the near-ultraviolet spectral region of biogenic secondary organic aerosol aged with ammonia. Phys. Chem. Chem. Phys. 2014, 16 (22), 10629-10642.

(52) Washenfelder, R. A.; Flores, J. M.; Brock, C. A.; Brown, S. S.; Rudich, Y. Broadband measurements of aerosol extinction in the ultraviolet spectral region. Atmos. Meas. Tech. 2013, 6 (4), 861-877.

(53) Michel Flores, J.; Bar-Or, R. Z.; Bluvshtein, N.; Abo-Riziq, A.; Kostinski, A.; Borrmann, S.; Koren, I.; Koren, I.; Rudich, Y. Absorbing aerosols at high relative humidity: linking hygroscopic growth to optical properties. Atmos. Chem. Phys. 2012, 12 (12), 5511-5521.

(54) Lang-Yona, N.; Rudich, Y.; Segre, E.; Dinar, E.; Abo-Riziq, A. Complex Refractive Indices of Aerosols Retrieved by Continuous Wave-Cavity Ring Down Aerosol Spectrometer. Anal. Chem. 2009, 81 (5), 1762-1769.

(55) Abo Riziq, A.; Erlick, C.; Dinar, E.; Rudich, Y. Optical properties of absorbing and non-absorbing aerosols retrieved by cavity ring down (CRD) spectroscopy. Atmos. Chem. Phys. 2007, 7 (6), $1523-1536$

(56) Yeh, G. K.; Claflin, M. S.; Ziemann, P. J. Products and Mechanism of the Reaction of 1-Pentadecene with NO3 Radicals and the Effect of a - ONO2 Group on Alkoxy Radical Decomposition. J. Phys. Chem. A 2015, 119 (43), 10684-10696.

(57) Claflin, M. S.; Ziemann, P. J. Identification and Quantitation of Aerosol Products of the Reaction of $\beta$-Pinene with NO3 Radicals and Implications for Gas- and Particle-Phase Reaction Mechanisms. J. Phys. Chem. A 2018, 122 (14), 3640-3652.

(58) Bianchi, F.; Kurtén, T.; Riva, M.; Mohr, C.; Rissanen, M. P.; Roldin, P.; Berndt, T.; Crounse, J. D.; Wennberg, P. O.; Mentel, T. F.; Wildt, J.; Junninen, H.; Jokinen, T.; Kulmala, M.; Worsnop, D. R.; 
Thornton, J. A.; Donahue, N.; Kjaergaard, H. G.; Ehn, M. Highly Oxygenated Organic Molecules (HOM) from Gas-Phase Autoxidation Involving Peroxy Radicals: A Key Contributor to Atmospheric Aerosol. Chem. Rev. 2019, 119 (6), 3472-3509.

(59) Ehn, M.; Thornton, J. A.; Kleist, E.; Sipila, M.; Junninen, H.; Pullinen, I.; Springer, M.; Rubach, F.; Tillmann, R.; Lee, B.; LopezHilfiker, F.; Andres, S.; Acir, I. H.; Rissanen, M.; Jokinen, T.; Schobesberger, S.; Kangasluoma, J.; Kontkanen, J.; Nieminen, T.; Kurten, T.; Nielsen, L. B.; Jorgensen, S.; Kjaergaard, H. G.; Canagaratna, M.; Maso, M. D.; Berndt, T.; Petaja, T.; Wahner, A.; Kerminen, V. M.; Kulmala, M.; Worsnop, D. R.; Wildt, J.; Mentel, T. F. A large source of low-volatility secondary organic aerosol. Nature 2014, 506 (7489), 476-9.

(60) Mentel, T. F.; Springer, M.; Ehn, M.; Kleist, E.; Pullinen, I.; Kurtén, T.; Rissanen, M.; Wahner, A.; Wildt, J. Formation of highly oxidized multifunctional compounds: autoxidation of peroxy radicals formed in the ozonolysis of alkenes - deduced from structureproduct relationships. Atmos. Chem. Phys. 2015, 15 (12), 6745-6765. (61) Berndt, T.; Richters, S.; Jokinen, T.; Hyttinen, N.; Kurten, T.; Otkjaer, R. V.; Kjaergaard, H. G.; Stratmann, F.; Herrmann, H.; Sipila, M.; Kulmala, M.; Ehn, M. Hydroxyl radical-induced formation of highly oxidized organic compounds. Nat. Commun. 2016, 7, 13677.

(62) Berndt, T.; Scholz, W.; Mentler, B.; Fischer, L.; Herrmann, H.; Kulmala, M.; Hansel, A. Accretion Product Formation from Self- and Cross-Reactions of RO2 Radicals in the Atmosphere. Angew. Chem., Int. Ed. 2018, 57 (14), 3820-3824.

(63) Berndt, T.; Mentler, B.; Scholz, W.; Fischer, L.; Herrmann, H.; Kulmala, M.; Hansel, A. Accretion Product Formation from Ozonolysis and $\mathrm{OH}$ Radical Reaction of alpha-Pinene: Mechanistic Insight and the Influence of Isoprene and Ethylene. Environ. Sci. Technol. 2018, 52 (19), 11069-11077.

(64) Ng, N. L.; Canagaratna, M. R.; Zhang, Q.; Jimenez, J. L.; Tian, J.; Ulbrich, I. M.; Kroll, J. H.; Docherty, K. S.; Chhabra, P. S.; Bahreini, R.; Murphy, S. M.; Seinfeld, J. H.; Hildebrandt, L.; Donahue, N. M.; DeCarlo, P. F.; Lanz, V. A.; Prevot, A. S. H.; Dinar, E.; Rudich, Y.; Worsnop, D. R. Organic aerosol components observed in Northern Hemispheric datasets from Aerosol Mass Spectrometry. Atmos. Chem. Phys. 2010, 10 (10), 4625-4641.

(65) Ng, N. L.; Canagaratna, M. R.; Jimenez, J. L.; Zhang, Q.; Ulbrich, I. M.; Worsnop, D. R. Real-Time Methods for Estimating Organic Component Mass Concentrations from Aerosol Mass Spectrometer Data. Environ. Sci. Technol. 2011, 45 (3), 910-916.

(66) Hu, W.; Campuzano-Jost, P.; Day, D. A.; Croteau, P.; Canagaratna, M. R.; Jayne, J. T.; Worsnop, D. R.; Jimenez, J. L. Evaluation of the new capture vaporizer for Aerosol Mass Spectrometers (AMS) through laboratory studies of inorganic species. Atmos. Meas. Tech. 2017, 10 (8), 2897-2921.

(67) Struckmeier, C.; Drewnick, F.; Fachinger, F.; Gobbi, G. P.; Borrmann, S. Atmospheric aerosols in Rome, Italy: sources, dynamics and spatial variations during two seasons. Atmos. Chem. Phys. 2016, 16 (23), 15277-15299.

(68) Farmer, D. K.; Matsunaga, A.; Docherty, K. S.; Surratt, J. D.; Seinfeld, J. H.; Ziemann, P. J.; Jimenez, J. L. Response of an aerosol mass spectrometer to organonitrates and organosulfates and implications for atmospheric chemistry. Proc. Natl. Acad. Sci. U. S. A. 2010, 107 (15), 6670-6675.

(69) Xu, L.; Suresh, S.; Guo, H.; Weber, R. J.; Ng, N. L. Aerosol characterization over the southeastern United States using highresolution aerosol mass spectrometry: spatial and seasonal variation of aerosol composition and sources with a focus on organic nitrates. Atmos. Chem. Phys. 2015, 15 (13), 7307-7336.

(70) Bruns, E. A.; Perraud, V.; Zelenyuk, A.; Ezell, M. J.; Johnson, S. N.; Yu, Y.; Imre, D.; Finlayson-Pitts, B. J.; Alexander, M. L. Comparison of FTIR and Particle Mass Spectrometry for the Measurement of Particulate Organic Nitrates. Environ. Sci. Technol. 2010, 44 (3), 1056-1061.

(71) Fry, J. L.; Kiendler-Scharr, A.; Rollins, A. W.; Brauers, T.; Brown, S. S.; Dorn, H. P.; Dubé, W. P.; Fuchs, H.; Mensah, A.; Rohrer, F.; Tillmann, R.; Wahner, A.; Wooldridge, P. J.; Cohen, R. C.
SOA from limonene: role of NO3 in its generation and degradation. Atmos. Chem. Phys. 2011, 11 (8), 3879-3894.

(72) Fry, J. L.; Kiendler-Scharr, A.; Rollins, A. W.; Wooldridge, P. J.; Brown, S. S.; Fuchs, H.; Dubé, W.; Mensah, A.; dal Maso, M.; Tillmann, R.; Dorn, H. P.; Brauers, T.; Cohen, R. C. Organic nitrate and secondary organic aerosol yield from $\mathrm{NO} 3$ oxidation of $\beta$-pinene evaluated using a gas-phase kinetics/aerosol partitioning model. Atmos. Chem. Phys. 2009, 9 (4), 1431-1449.

(73) Rollins, A. W.; Kiendler-Scharr, A.; Fry, J. L.; Brauers, T.; Brown, S. S.; Dorn, H. P.; Dubé, W. P.; Fuchs, H.; Mensah, A.; Mentel, T. F.; Rohrer, F.; Tillmann, R.; Wegener, R.; Wooldridge, P. J.; Cohen, R. C. Isoprene oxidation by nitrate radical: alkyl nitrate and secondary organic aerosol yields. Atmos. Chem. Phys. 2009, 9 (18), 6685-6703.

(74) Boyd, C. M.; Sanchez, J.; Xu, L.; Eugene, A. J.; Nah, T.; Tuet, W. Y.; Guzman, M. I.; Ng, N. L. Secondary organic aerosol formation from the $\beta$-pinene $+\mathrm{NO} 3$ system: effect of humidity and peroxy radical fate. Atmos. Chem. Phys. 2015, 15 (13), 7497-7522.

(75) Boyd, C. M.; Nah, T.; Xu, L.; Berkemeier, T.; Ng, N. L. Secondary Organic Aerosol (SOA) from Nitrate Radical Oxidation of Monoterpenes: Effects of Temperature, Dilution, and Humidity on Aerosol Formation, Mixing, and Evaporation. Environ. Sci. Technol. 2017, 51 (14), 7831-7841.

(76) Liu, P. F.; Abdelmalki, N.; Hung, H. M.; Wang, Y.; Brune, W. H.; Martin, S. T. Ultraviolet and visible complex refractive indices of secondary organic material produced by photooxidation of the aromatic compounds toluene and m-xylene. Atmos. Chem. Phys. 2015, 15 (3), 1435-1446.

(77) Saleh, R.; Hennigan, C. J.; McMeeking, G. R.; Chuang, W. K.; Robinson, E. S.; Coe, H.; Donahue, N. M.; Robinson, A. L. Absorptivity of brown carbon in fresh and photo-chemically aged biomass-burning emissions. Atmos. Chem. Phys. 2013, 13 (15), 76837693.

(78) Sumlin, B. J.; Pandey, A.; Walker, M. J.; Pattison, R. S.; Williams, B. J.; Chakrabarty, R. K. Atmospheric Photooxidation Diminishes Light Absorption by Primary Brown Carbon Aerosol from Biomass Burning. Environ. Sci. Technol. Lett. 2017, 4 (12), 540-545.

(79) Li, C.; He, Q.; Schade, J.; Passig, J.; Zimmermann, R.; Meidan, D.; Laskin, A.; Rudich, Y. Dynamic changes in optical and chemical properties of tar ball aerosols by atmospheric photochemical aging. Atmos. Chem. Phys. 2019, 19 (1), 139-163.

(80) Bluvshtein, N.; Lin, P.; Flores, J. M.; Segev, L.; Mazar, Y.; Tas, E.; Snider, G.; Weagle, C.; Brown, S. S.; Laskin, A.; Rudich, Y. Broadband optical properties of biomass-burning aerosol and identification of brown carbon chromophores. J. Geophys. Res. Atmos. 2017, 122 (10), 5441-5456.

(81) Jiang, H. H.; Frie, A. L.; Lavi, A.; Chen, J. Y.; Zhang, H. F.; Bahreini, R.; Lin, Y. H. Brown Carbon Formation from Nighttime Chemistry of Unsaturated Heterocyclic Volatile Organic Compounds. Environ. Sci. Technol. Lett. 2019, 6 (3), 184-190.

(82) Nakayama, T.; Sato, K.; Matsumi, Y.; Imamura, T.; Yamazaki, A.; Uchiyama, A. Wavelength and NOx dependent complex refractive index of SOAs generated from the photooxidation of toluene. Atmos. Chem. Phys. 2013, 13 (2), 531-545.

(83) Li, C.; He, Q.; Schade, J.; Passig, J.; Zimmermann, R.; Meidan, D.; Laskin, A.; Rudich, Y. Dynamic changes in optical and chemical properties of tar ball aerosols by atmospheric photochemical aging. Atmos. Chem. Phys. 2019, 19 (1), 139-163.

(84) Tong, H. J.; Arangio, A. M.; Lakey, P. S. J.; Berkemeier, T.; Liu, F. B.; Kampf, C. J.; Brune, W. H.; Poschl, U.; Shiraiwa, M. Hydroxyl radicals from secondary organic aerosol decomposition in water. Atmos. Chem. Phys. 2016, 16 (3), 1761-1771.

(85) Zhang, X.; Zhang, H.; Xu, W.; Wu, X.; Tyndall, G. S.; Orlando, J. J.; Jayne, J. T.; Worsnop, D. R.; Canagaratna, M. R. Molecular characterization of alkyl nitrates in atmospheric aerosols by ion mobility mass spectrometry. Atmos. Meas. Tech. 2019, 12 (10), 55355545.

(86) Redmond, H.; Thompson, J. E. Evaluation of a quantitative structure-property relationship (QSPR) for predicting mid-visible 
refractive index of secondary organic aerosol (SOA). Phys. Chem. Chem. Phys. 2011, 13 (15), 6872-6882.

(87) Bosque, R.; Sales, J. Polarizabilities of Solvents from the Chemical Composition. J. Chem. Inf. Comput. Sci. 2002, 42 (5), $1154-1163$.

(88) Jacobson, M. Z.; Kaufman, Y. J.; Rudich, Y. Examining feedbacks of aerosols to urban climate with a model that treats 3-D clouds with aerosol inclusions. J. Geophys. Res. 2007, 112 (D24), D24205.

(89) Saleh, R. From Measurements to Models: Toward Accurate Representation of Brown Carbon in Climate Calculations. Curr. Pollut. Rep. 2020, 6 (2), 90-104. 